\title{
The Relationship Between Fuzzy Coefficient of Innovation, Market Power, and Stock Return: Evidence of Competition-Aversion
}

\author{
Samaneh Noraniazad ${ }^{1}$ \\ noraniazad@pnu.ac.ir \\ Erfaneh Rasekh Jahromi \\ rasekh@pnu.ac.ir
}

\begin{abstract}
The main purpose of this article is to test the relationship between market power, innovation, and stock return in Tehran security market. To meet this end, the data of 153 institutions in Tehran security market over the period of 1997-2018 were used through a panel smooth transition approach. The results indicate the existence of a nonlinear relationship among variables in innovation and stock returns equations. Also, in the innovation coefficient equation, with an increase in market power as a transition variable to the threshold level, the innovation coefficient was increasing and significant, and passing through this level it was decreasing and significant. In addition, in the stock return equation, this trend maintains increasing innovation before and after the threshold level. In general, the results of innovation intensity and stock returns equations show that in the firms active in Tehran Stock Exchange, there was an asymmetrical and U-inverse relationship between the market power, innovation, and stock return. Moreover, evidence of competitionaversion effects was confirmed in most stock exchange firms.
\end{abstract}

\section{Keywords: Threshold Level, Innovation Coefficient, Market Power, Stock Returns, Security Market, Panel Smooth Transition Regression Model (PSTR).}

JEL Classification: L13, L22, G40, C59.

1. Assistant Professor of Economics, Payame Noor University, Tehran, Iran (Corresponding Author).

2. Faculty Member of Economics, Payame Noor University, Tehran, Iran. 


\section{آزمون رابطه ضريب فازى نوآورى، قدرت بازارى، و وابت بازدهى سهام: شواهدى از اثرهائ رقابت قابت تريزى بازي}

noraniazad@pnu.ac.ir ।

استاديار كروه اقتصاد، دانشَاه يِام نور، تهران، ايران (نويسنده مسئول).

عرفانه راسخ جهرمى مرونى

rasekh@pnu.ac.ir

مربى گروه اقتصاد، دانشَاه يِيام نور، تهران، ايران

קكيده: هدف محورى يزوهش حاضر، بررسى رابطه بين ضريب نوآورى، قدرت بازارى، و بازدهى

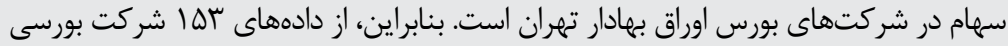

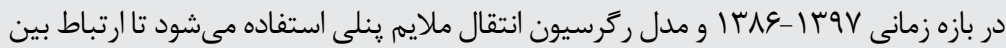

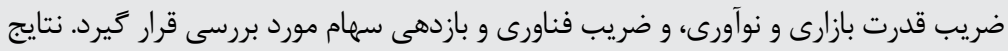

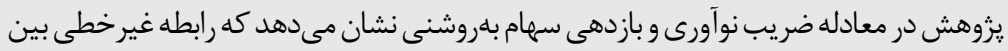

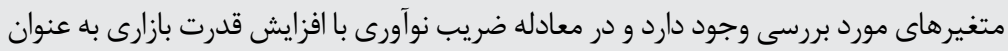

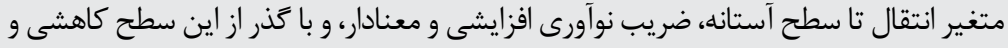

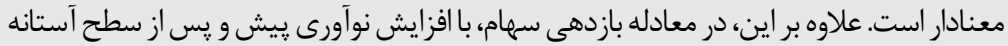

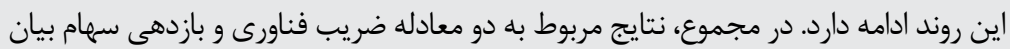

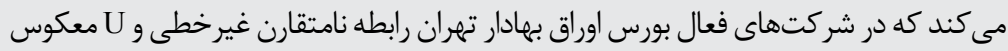

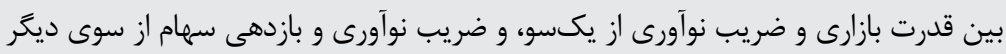

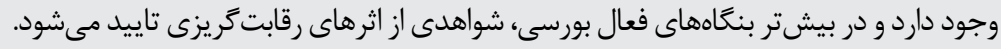

كليدوازهها: سطح آستانهاى، ضريب نوآورى، درجه رقابت، بازدهى سهام، بورس اوراق بهادار، ركرسيون انتقال ملايم ينلى (PSTR). طبقهبندى C59, G40, L22, L13 , :JEL. 


\section{هoloto}

اگر حه در اقتصاد رو به رشد امروزى، مشاركت در فعاليتهاى نوآور مىتواند فرصتهاى لازم را براى ايجاد و حفظ قدرت بازارى، عملكرد، و بازدهى بالاتر بنعَاهها فراهم نمايد، اما رقابت نيز اين

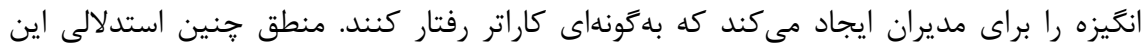
است كه نيروهاى انضباطى رقابت، مديران نالايق را بهسرعت از بازار بيرون مىكند. در واقع، در

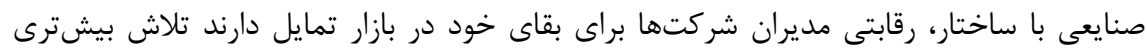

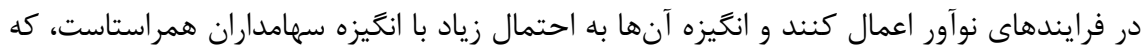
اين امر افزايش بازدهى شركت را به دنبال دارد (Grullon \& Michaely, 2008; He, 2012). از دهه

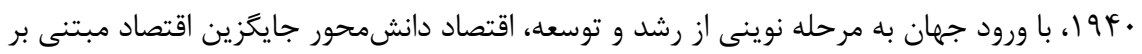

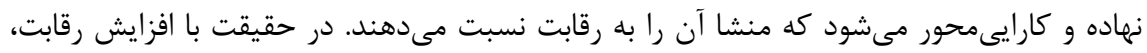

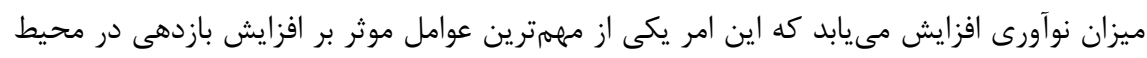

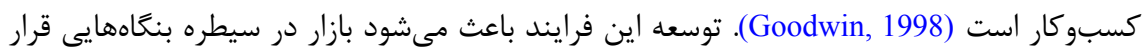

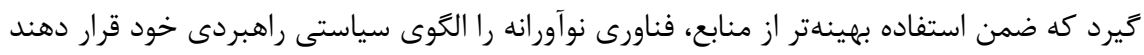

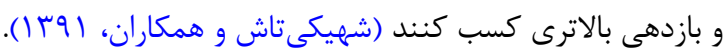

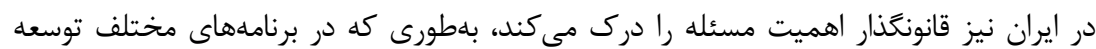

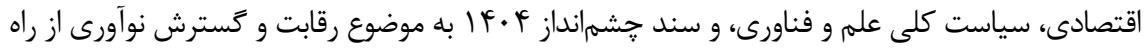
افزايش تحقيق و توسعه اشاره و تاكيد مىشود. همجنين، از آنجايى كه در بازارهاى مالى، سرمايهكذاران بلهور دائم در حال جستجوى الكوهايى براى افزايش بازدهى سهام و عوامل موثر بر آن به منظور بكار

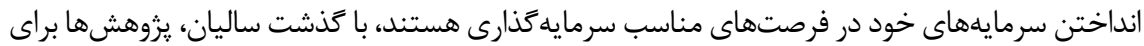

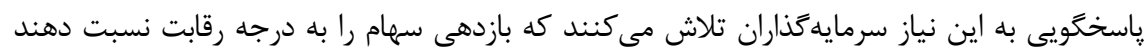
(Clarke \& Davies, 1982; Clarke et al., 1984; Alfranca et al., 2014; Dhanora et al., 2018) يزروهشگران نشان مىدهند كه درجههاى مختلف رقابت باعث رفتارهاى متفاوتى از قبيل قيمت گذارى، تهاجم، تحقيقوتوسعه، تبليغ، و انتخاب نوع نوآورى مىشود كه منشا بازدهى متفاوتى است. به عبارت دئ ديكر،

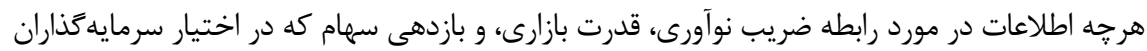

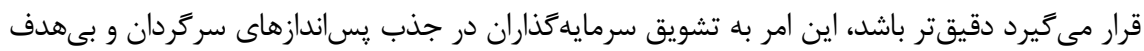

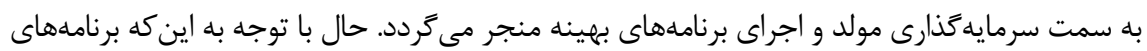

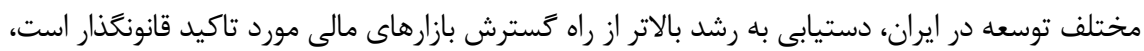


ضرورى است در اين بازارها براى رسيدن به بازدهى هدف به افزايش نوآورى و گسترش فعاليت فناورانه

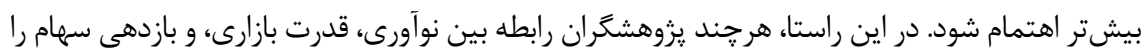

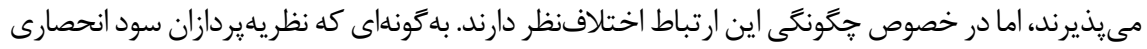
معتقدند نوآورى با قدرت بازارى و بازدهى سهام همبستكى مثبت دارد، يعنى بنكًاههايى با قدرت بازارى

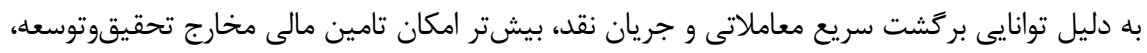

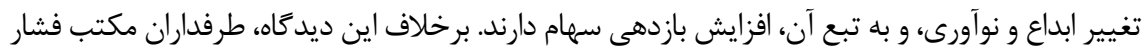

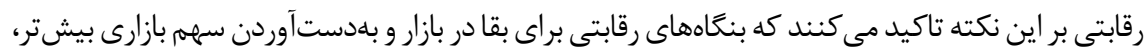

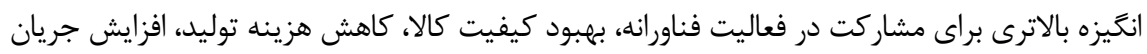
نقد، و بازدهى سهام دارند. در حالى كه در ديد

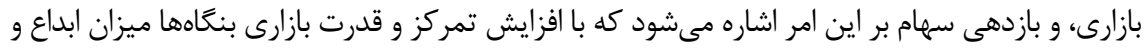

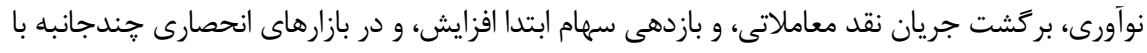

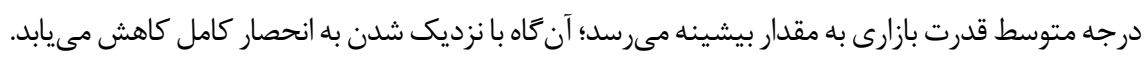

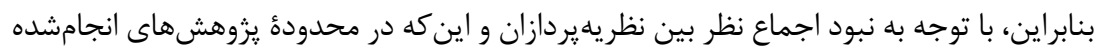

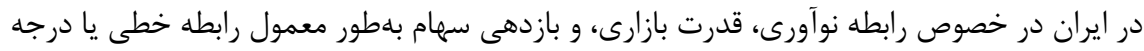

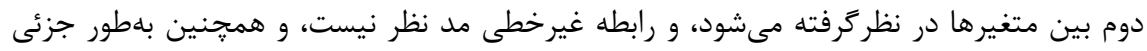

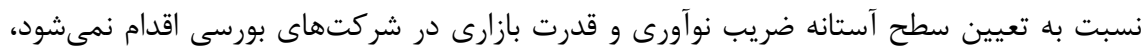

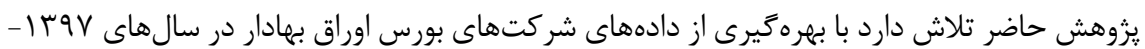

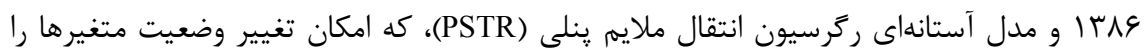

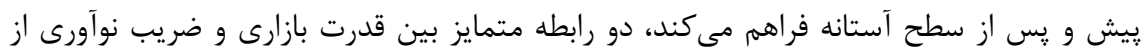

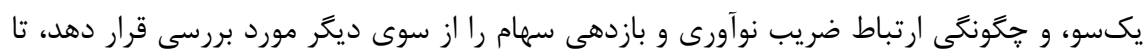
به اين :رسش يֶاسخ دهد كه در شركتهاى فعال بورس اوراق بهادار تهران رابطه بين ضريب فناورى،

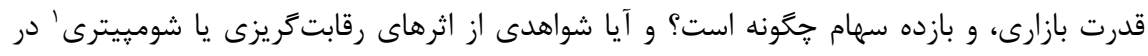
بورس اوراق بهادار وجود دارد؟ در اين راستا، فرضيه وجود رابطه خطى يا غيرخطى در دو دمانى معادله ضريب نوآورى و بازدهى سهام مورد آزمون قرار مى

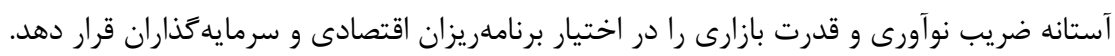

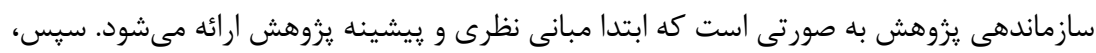


در بخش روششناسى يروهش ضمن معرفى جامعه و نمونه آمارى، به ساختار مدل و رهيافت تخمين

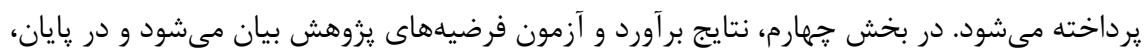
به بحث و نتيجه گيرى يرداخته مى مود.

\section{مبانى نظرى يزوهش}

نوآورى به ارائه محصول يا دانش جديد، بكارگيرى روشها و فرايندهاى نوين توليدى، و انتقال اين فرايندها به بازار تعريف مىشود كه مىتوان در دو گروه نوآورى تكنيكى شامل توليد محصولات جديد

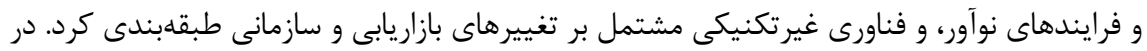
واقع، نوآورى تكنيكى كه به تسريع توليد، معرفى، و انتشار محصولات جديد منجر مىشود از فرايند تحقيقوتوسعه حاصل مىشود و به عنوان فعاليتى است كه اين فرصت را به شركتها مي دهد كه با حفظ قدرت انحصارى خود در بازار، زمينه را براى افزايش بازدهى سهام فراهم كنند (Gunday et al., 2011). از طرفى، رقابت نيرويى است كه به نظمبخشى كار مديران و افزايش كارايى اقتصادى منجر ميىشود. در واقع، درجههاى متفاوت رقابت، اطلاعاتى را در خصوص تحقيقوتوسعه، ميزان مشاركت در فعاليت

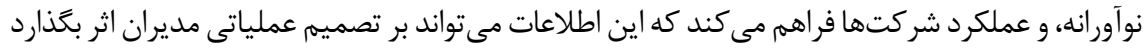
و به توانايى آنها در ارزيابى رفتار و عملكرد شركتها كمك شايانى كند (Hart, 1983). بيشتر مبركئر مباحث نظرى در خصوص رابطه نوآورى، قدرت بازارى، و بازدهى سهام به دو نظريه رقيب سود انحصارى و فشار

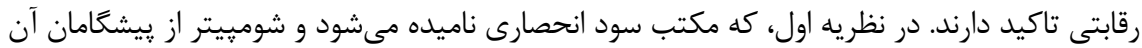

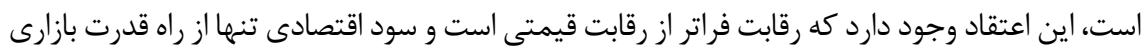

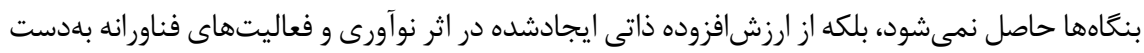
مى آيد. شومييتر، كارايى يويا' را به عنوان فرايند تخريب خلاقَ توصيف ميى كند (Schumpeter, 1942). اين فرايند مبناى رشد فناورى و سازماندهى جديد است كه به توليد محصولات و فرايندهاى نوين توليد منجر مىشود و در نهايت، افزايش استانداردهاى زندگى را به همراه دارد. به اعتقاد وى، سود در طي طي

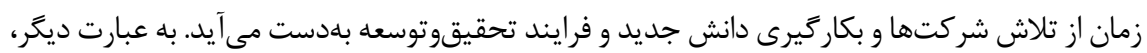

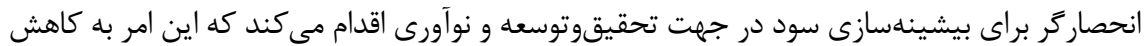
هزينه توليد، افزايش كارايى شركتها، تقويت قدرت انحصارى، و افزايش بازدهى سهام منجر مى شيود 


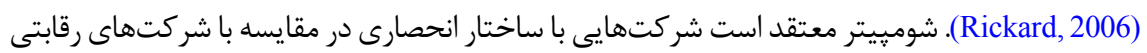

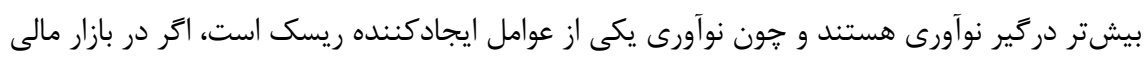

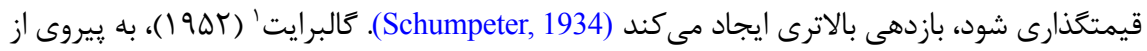
شوميِتر معتقد است كه شركتهاى بزرى در مقايسه با شركتهاى كوجى تمايل بيشترى برى براى انجام

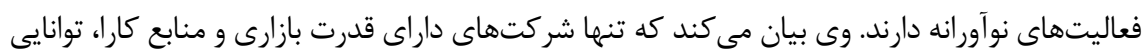

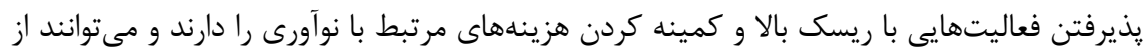

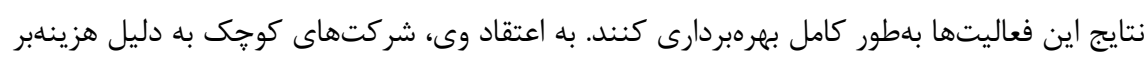

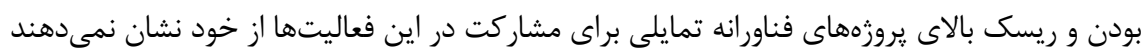

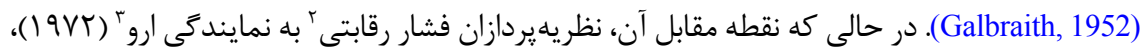

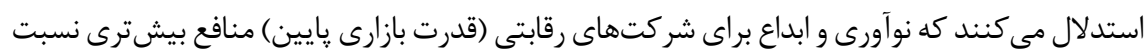

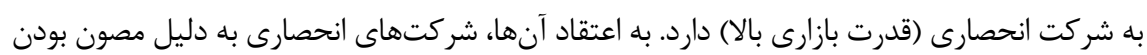

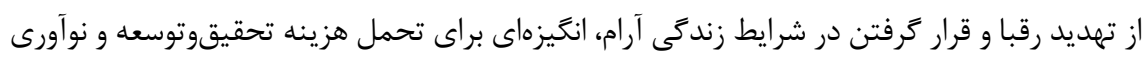

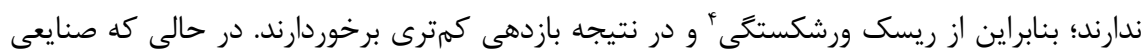

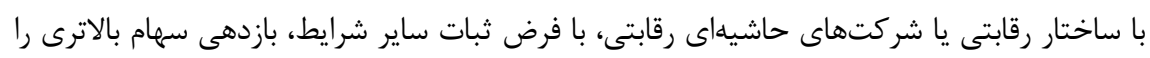

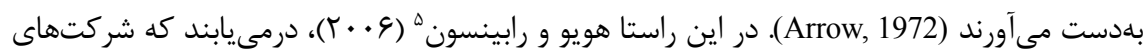

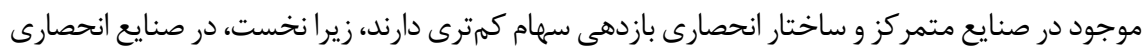

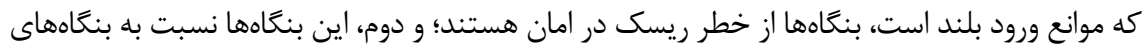
رقابتى به دليل نداشتن ترس از رقبا كمتر با ريسك نوآورى مواجه هستند. بنابراين، سرمايهُ كذاران انتظار بازدهى سهام كمتر با ريسك و خطر نوآورى كمترى دارند (Hou \& Robinson, 2006). هيرشليفر و و

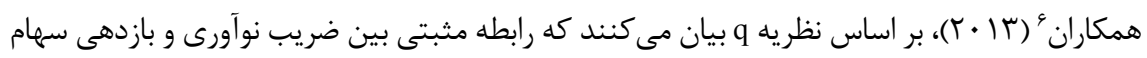

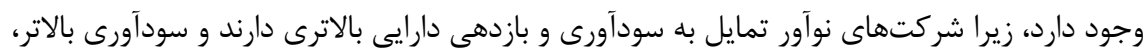

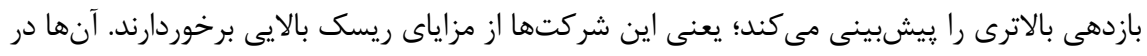

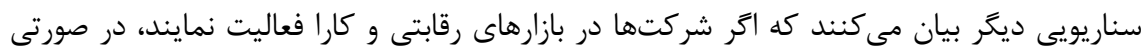

1. Galbraith

2. Competition Pressure

3. Arrow

4. Distress Risk

$11 \%$

5. Hou \& Robinson

6. Hirshleifer et al. 
كه سرمايه گذارى در فعاليت نوآورانه ريسك بالايى داشته باشد، بازدهى بالاترى بهدست مى آورند و

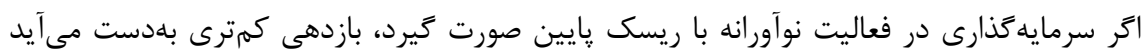

(Hirshleifer et al., 2013)

در اين ميان، گروهى ديخر از يزوهشگران با در نظرگرفتن ناطمينانى در ساختار بازار، رابطه معكوسى را بين قدرت بازارى، نوآورى، و بازدهى سهام مشاهده مى كنند. آكيون و همكاران' (ه ه • r)،

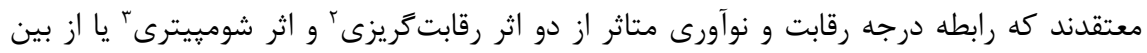

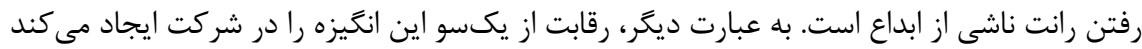

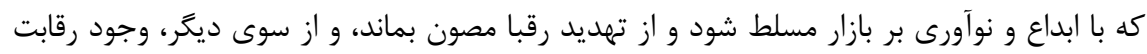
موجب كاهش انخيزه براى ابداع مىشود، زيرا شركت نكران اين موضوع است كه نتايج و منافع ابداع

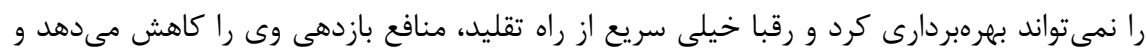

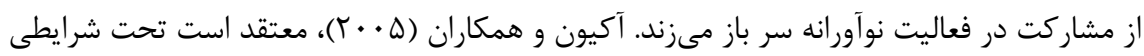

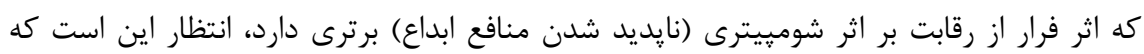

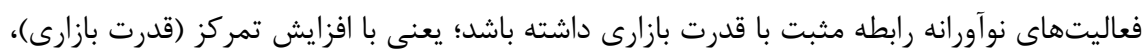

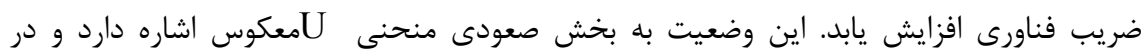

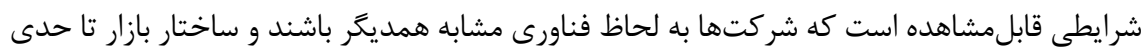

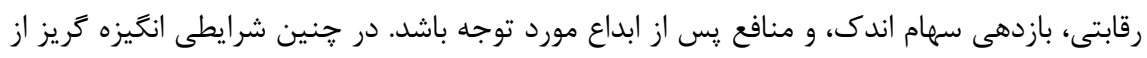

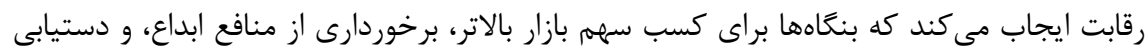

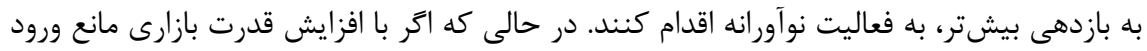

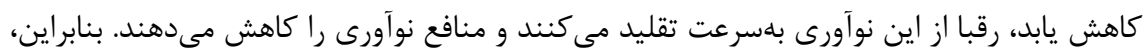

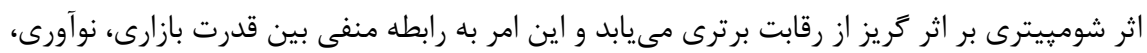
و بازدهى سهام منجر مىشود. البته اين وضعيت در شرايطى محقق مىشود كه نخست، ساختار بازار

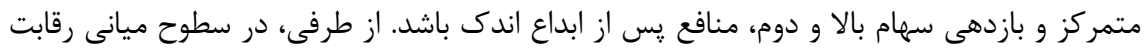

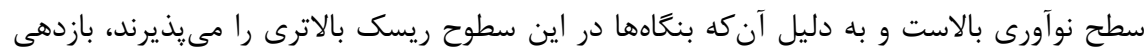

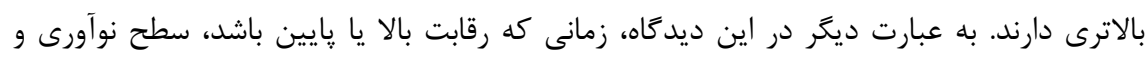

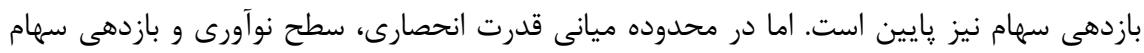

1. Aghion et al.

2. Escape Competition

3. Schumpeterian Effect 
بالاست. از اينرو، تركيب اين نتايج مىتواند تاييدى بر رابطه U معكوس بين قدرت بازارى، نوآورى، و بازدهى سهام باشد (Aghion et al., 2005). با جمعبندى ديدكاههاى اشارهشه ملاحظه مىشود كه در بيشتر يزوهشها اتفاقنظر در خصوص رابطه قدرت بازارى، نوآورى، و بازدهى سهام وجود ندارد. بنابراين، لازم است بهطور تجربى

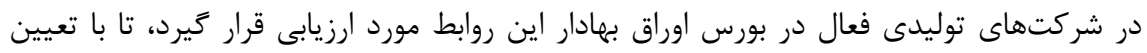
سطح آستانه بهينه، ضريب نوآورى و قدرت بازارى راهُشايى برى براى سياستخذاران و سرمايهداران

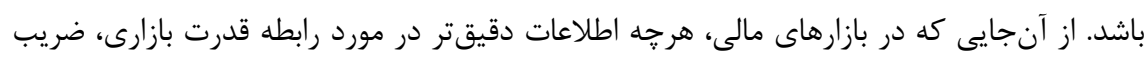

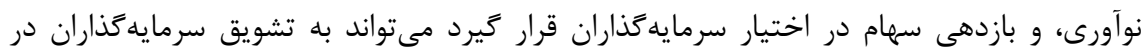

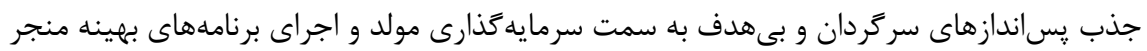
گردد، بنابراين بررسى رابطه متغيرهاى يادشده، كانون توجه مقامات نظارتى، سرمايه گذاران نهادى،

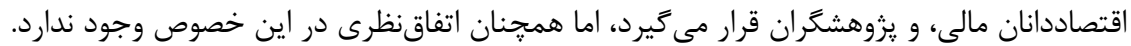

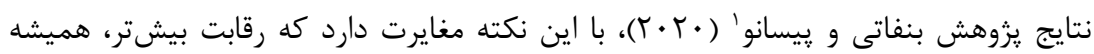

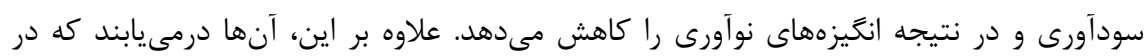
شرايط انحصارى كه سودآورى زياد است، امكان تامين اعتبار براى مشاركت در نوآورى وجود دارد، اما

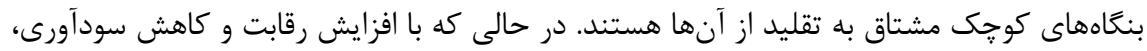

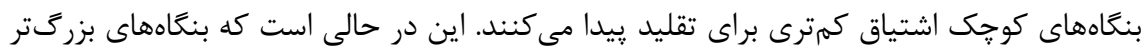

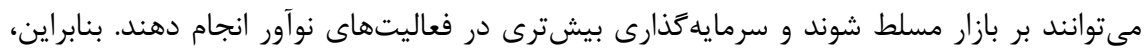

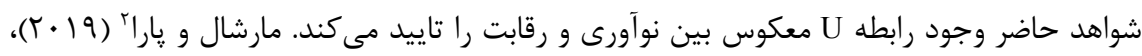

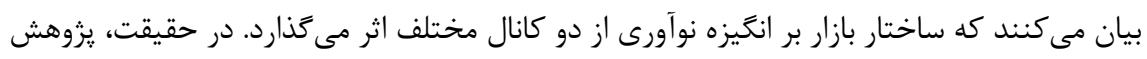
آنها گوياى اين است كه كاهش رقابت بلهطور مستقيم با كاهش تعداد بنعاههاى نوآورانه و بلهطور غيرمستقيم با تغيير سود در بازار محصول بر نتايج تحقيقوتوسعه موثر است. ولى رابطه بين رقابت

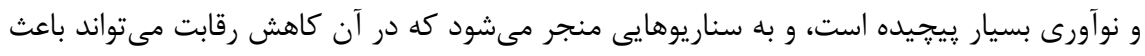

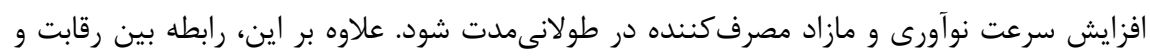

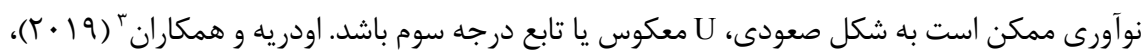
بررسى مى كنند كه جهت گيرى بازار و نوآورى بر مزيت رقابتى اثر مثبت و معنادارى دارد. همجنين،

\section{Bonfatti \& Pisano}


مزيت رقابتى بر عملكرد كسبوكار اثر مثبت و معنادارى دارد. به عبارت ديخر، جهت

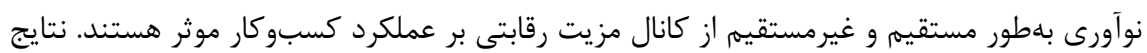

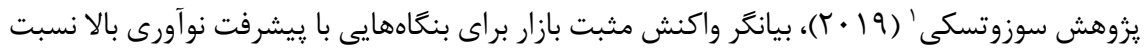

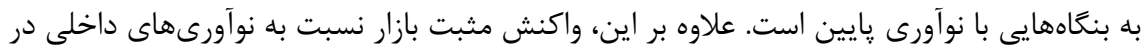

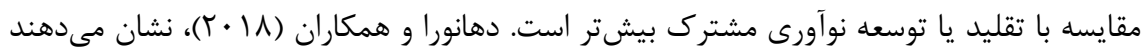

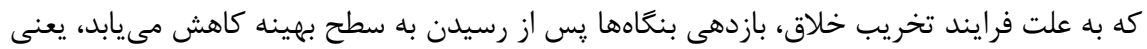

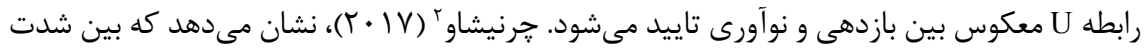
تحقيقوتوسعه و رقابت رابطه U معكوس وجود دارد، در حالى كه بين تلاش براى تحقيقوتوسعه و

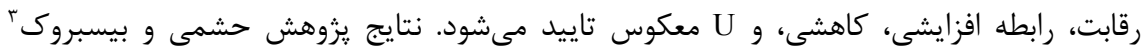

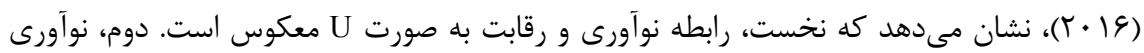
كيفيت محصول شركتهاى رقيب را با فرض ثبات كيفيت محصول خود شركت كاهش مى دهد، در

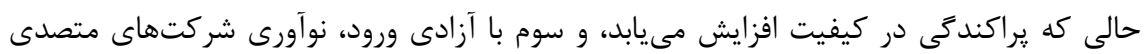

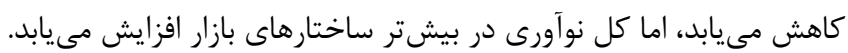

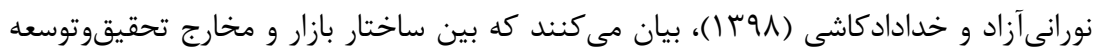
رابطه غيرخطى وجود دارد. علاوه بر اين، تنها در \& درصد صنايع، تمركز و نوآورى بالاست و در بيشتر

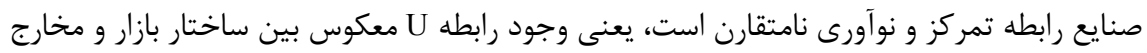

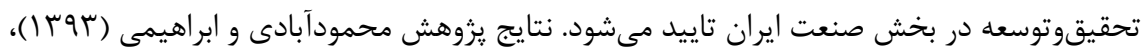
نشان مىدهد كه بين شاخص رقابت با نسبت سود سهام يرداختى به فروش، سود سهام يرداختى به

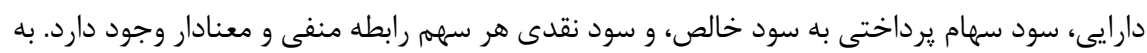

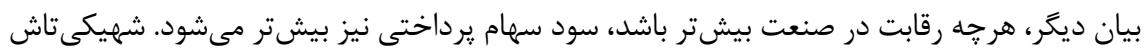

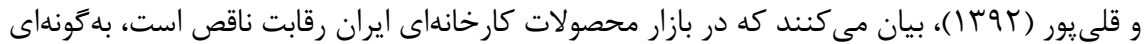

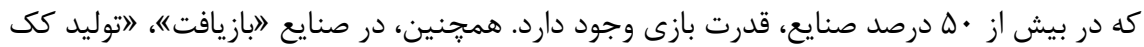

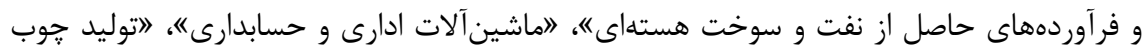
و محصولات جوبى"، اساخت كالا از نى و مواد حصيرى"، "اساخت فلزات اساسى"، و \انتشار، جاب، و تكثير رسانههاى ضبطشده، بيشترين انعطافنايذيرى در بازار نيروى كار وجود دارد. كردبجهه و

\section{Szutowski}

2. Chernyshev

3. Hashmi \& Biesebroeck 


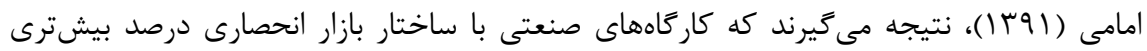
از مخارج را به فعاليت تحقيقوتوسعه اختصاص مى دهند. شهيكى تاش و همكاران (I (1))، نشان Uي دهند كه بين ساختار بازار و بازدهى سهام رابطه معنادارى وجود دارد و اين رابطه به صورت معكوس است، يعنى با افزايش تمركز تا نقطه بيشينه، و وِ از اين نقطه بلهترتيب بازدهى افزايش يا

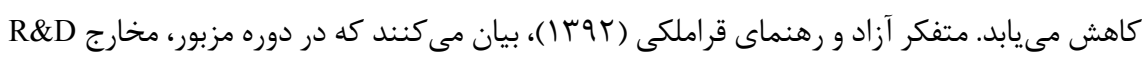

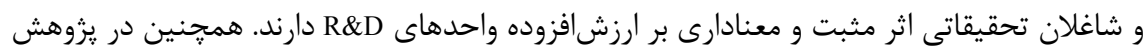

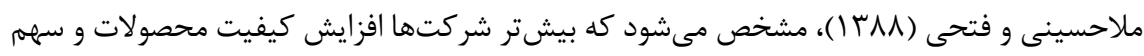
بازارى خود را در يرتو جنبdهاى نوآورى دنبال ميى كنند.

\section{روش}

جامعه آمارى يزوهش حاضر، كليه شركتهاى فعال در بزرىترين بازار مالى ايران (بورس اوراق

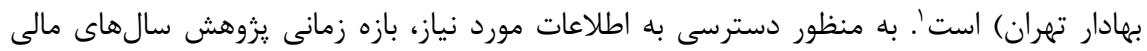

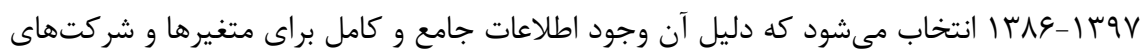
مورد بررسى است. علاوه بر اين، براى انتخاب نمونه ابتدا شركتهاى سرمايهگذارى، واسطههاى

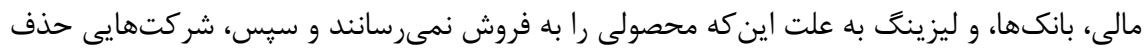

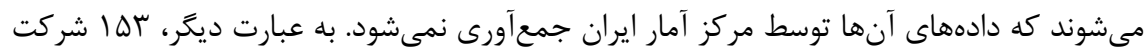
كه فعاليت آنها توليدى است و دادهايشان در دسترس است، نمونه آمارى ما را تشكيل مى دهدي.

\section{معرفى ساختار الكو}

به منظور مدلسازى رابطه قدرت بازارى، نوآورى، و بازدهى سهام با الهام از نظريههاى موجود در

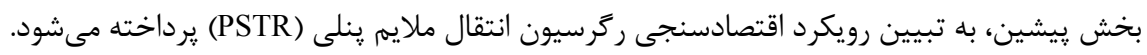

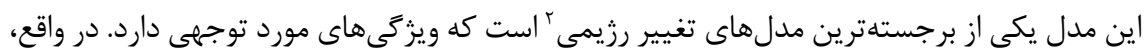

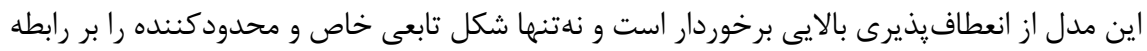
ميان متغيرها تحميل نمى كند، بلكه رابطه غيرخطى محتمل ميان متغيرها را با استفاده از تابع انتقال

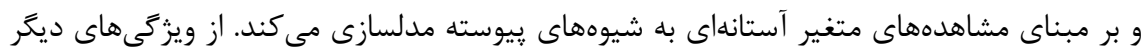


اين مدل آن است كه به ضرايب تخمينى اجازه مى دهد كه در طول زمان و براى مقاطع مختلف تغيير

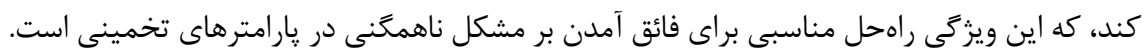

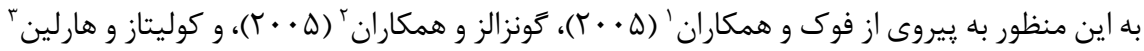

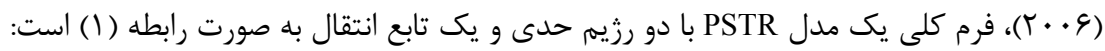

$y_{i t}=\mu_{i}+B_{0} X_{i t}+B_{1} X_{i t} G\left(q_{i t} ; \gamma, c\right)+U_{i t}$

$\mathrm{i}=1, \ldots, \mathrm{N}, \mathrm{t}=1, \ldots, \mathrm{T}$

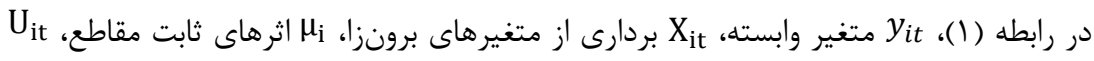

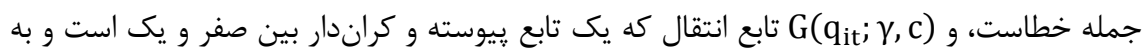
$G\left(q_{i t} ; \gamma, c\right)=\left\{\begin{array}{lr}1 & \text { if } q_{i t} \geq c \\ 0 & \text { othrwis }\end{array}\right.$

از طرفى، اين تابع انتقال توسط متغير آستانهاى تعيين مىشود و به صورت تابع لاجيستيكى (r)

$G\left(q_{i t} ; \gamma, c\right)=\left\{1+\exp \left[-\gamma \prod_{j=1}^{m}\left(q_{i t}-c_{j}\right)\right]\right\}^{-1}$ تصحيح مى گردد:

$$
\gamma>0, \mathrm{c}_{1} \leq \mathrm{c}_{2}, \ldots, \leq \mathrm{c}_{\mathrm{m}}
$$

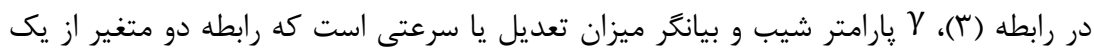

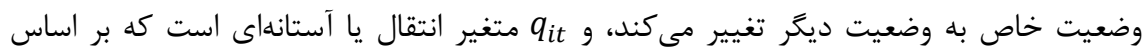

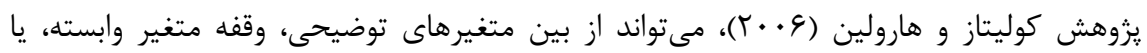
هر متغير ديكر خارج از مدل كه از حيث مبانى نظرى در ارتباط با مدل مورد بررسى است و عامل

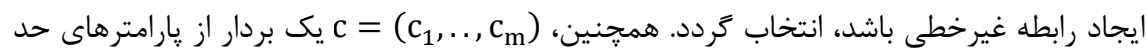

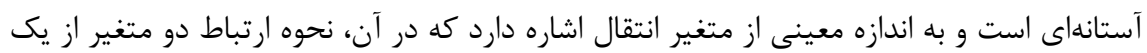

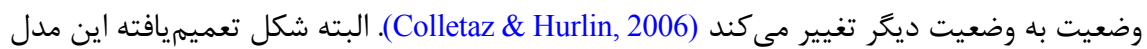
با بيش از يك تابع انتقال به صورت رابطه (أl) تصريح مى وصود:

1. Fok et al.

2. Gonzalez et al.

3. Colletaz \& Hurlin 
$y_{i t}=\mu_{i}+B_{0} X_{i t}+\sum_{j=1}^{r}\left[B_{j} X_{i t}\right] G_{j}\left(q_{i t}{ }^{j} ; \gamma_{j}, c_{j}\right)+U_{i t}$

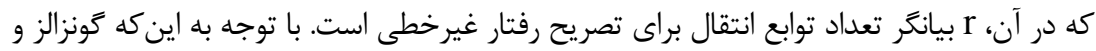

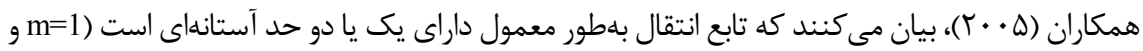

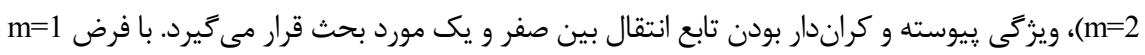

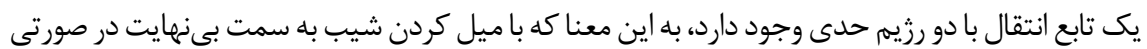

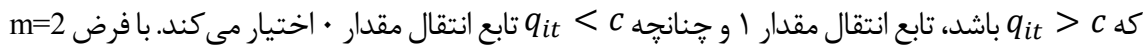

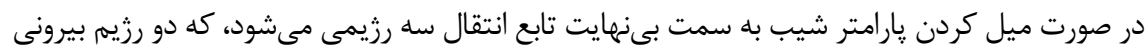

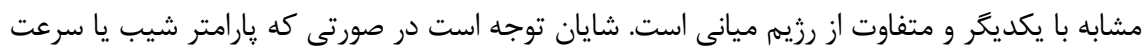

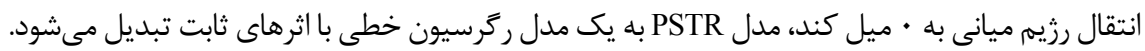

\section{مراحل تخمين}

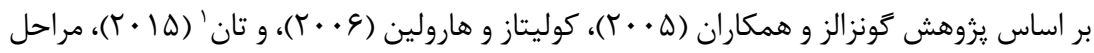

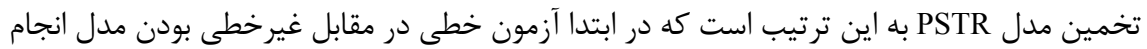

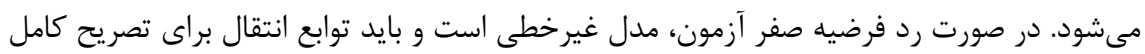

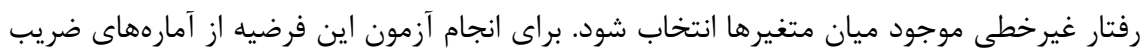
لاكرانز والد (LM توسط روابط (Q) محاسبه مىشوند:

$\mathrm{LM}_{\mathrm{w}}=\frac{\mathrm{TN}\left(\mathrm{SSR}_{0}-\mathrm{SSR}_{1}\right)}{\mathrm{SSR}_{0}} \quad \mathrm{LR}=-2\left[\log \left(\mathrm{SSR}_{1}\right)-\log \left(\mathrm{SSR}_{0}\right)\right]$ $\mathrm{LM}_{\mathrm{F}}=\left[\left(\mathrm{ESSR}_{0}-\mathrm{SSR}_{1}\right) / \mathrm{Km}\right] /\left[\mathrm{SSR}_{0} /(\mathrm{TN}-\mathrm{N}-\mathrm{mK})\right]$

كه در آن،

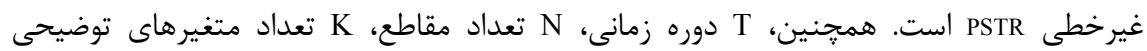
لحاظشده در مدل، و m تعداد حدهاى آستانهاى است. در شرايطى كه نتايج به وجود مدل غيرخطى

1. Thanh

2. Wald Lagrange Multiplier

3. Fischer Lagrange Multiplier

4. Likelihood Ratio 
دلالت داشته باشد، در مرحله بعدى بايد تعداد توابع انتقال براى تصريح كامل رفتار غيرخطى PSTR انتخاب شود. براى اين منظور، فرضيه صفر وجود يك تابع انتقال در مقابل فرضيه وجود دست كم دو

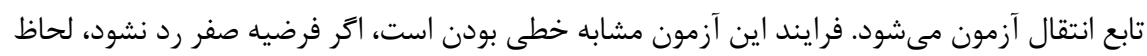

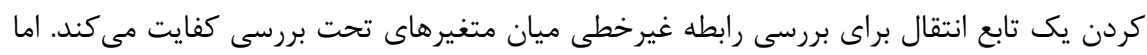

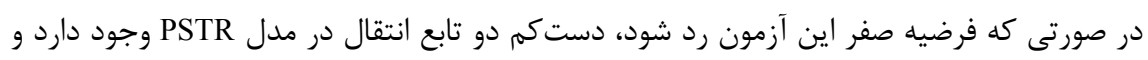
در ادامه بايد فرضيه صفر وجود دو تابع انتقال در مقابل فرضيه وجود دست كمم سه تابع انتقال آزمون

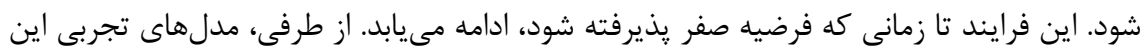

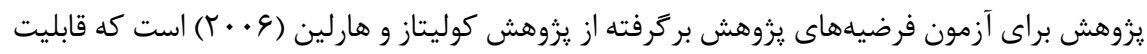

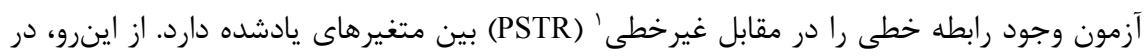

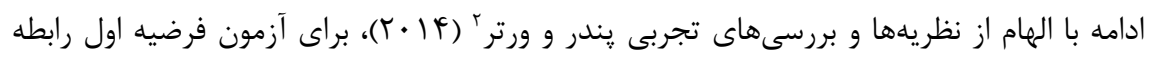
قدرت بازارى و نوآورى به صورت رابطه (9) تصريح مى شود: $\mathrm{RD}_{\text {it }}=\mu_{\mathrm{i}}+\mathrm{a}_{1} \mathrm{LI}_{\mathrm{it}}+\mathrm{a}_{2} \mathrm{PIS}_{\mathrm{it}}+\mathrm{a}_{3} \mathrm{CDR}_{\mathrm{it}}+\mathrm{a}_{4} \mathrm{KS}_{\text {it }}$

$+\sum_{j=1}^{r}\left[B_{1} L_{i t}+B_{2} P S_{i t}+B_{3} C R_{i t}+B_{4} K_{i t}\right] G_{j}\left(q_{i t}^{j} ; \gamma_{j}, c_{j}\right)+\varepsilon_{i t}^{(\varphi)}$

در روابط (ع)، i و بيانكر بنگاه و زمان، RD ضريب نوآورى به عنوان متغير وابسته، LI معيار سنجش قدرت بازارى به عنوان متغير مستقل،

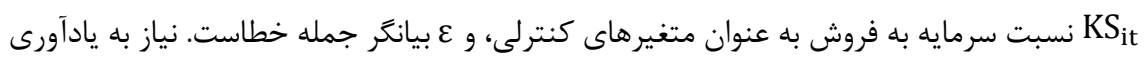

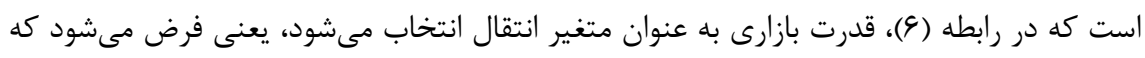

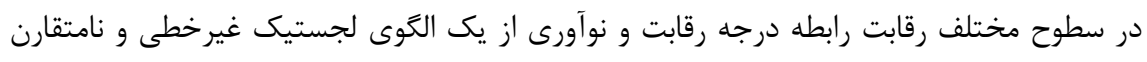

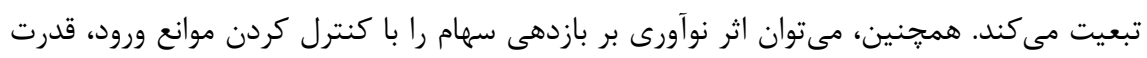

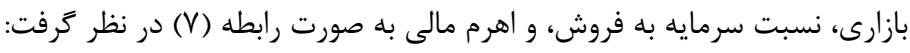

$$
\begin{aligned}
R_{i t}=\mu_{i}+a_{1} R_{i t} & +a_{2} L_{i t}+a_{3} C D D R_{i t}+a_{4} L e_{i t}+a_{5} K_{i t} \\
& +\sum_{j=1}^{r}\left[B_{1} R_{i t}+B_{2} L_{i t}+B_{3} C D R_{i t}+B_{4} L v_{i t}+B_{5} K_{i t}\right] G_{j}\left(q_{i t}^{j} ; \gamma_{j}, c_{j}\right)+\varepsilon_{i t}
\end{aligned}
$$

ا. آكيون و همكاران (ه · (Y)، تلاش مى كنند با استفاده از مدل بواسن و تابع نمايى رابطه غير خطى بين رقابت،

2. Peneder \& Wörter 


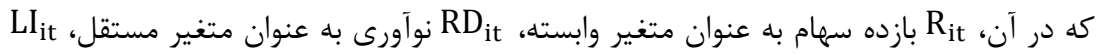

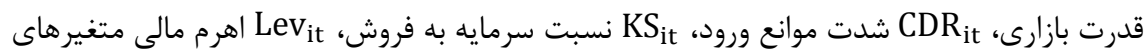
كنترلى، و ع بيانكر جمله خطاست. در اين رابطه، نوآورى به عنوان متغير انتقال است.

تعريف عملياتى متغيرها

تعريف عملياتى متغيرهاى اين يزوهش كه دادههاى خام آنها از پايگاه اطلاعات آمارى بورس

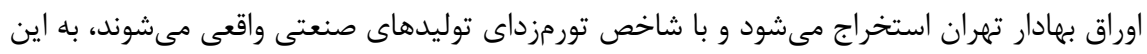
شرح است: درجه رقابت: متعارفترين معيار سنجش قدرت بازارى شركتها كه بيانكر توانايى شركت در

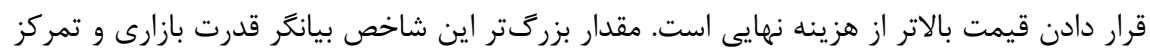
بازار در دست تعداد محدودى بنكاه است، در حالى كه مقدار كمتر آن گوياى ساختار رقابتى و تمركز بازار در دست تعداد محدود فعال اقتصادى است و با رابطه زير محاسبه ميىشود (Sharma, 2011). $\mathrm{PCM}=\mathrm{LI}=\frac{\text { Sale }- \text { CoGs }- \text { SGA }}{\text { Sale }}$

شدت مانع ورود: به مثابه سدى در مقابل تازمواردها به بازار عمل مى كند. هرجه اين شاخص

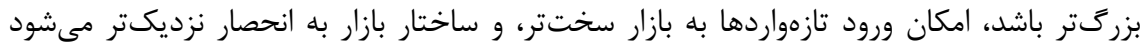

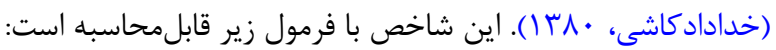
$\mathrm{CDR}=\frac{\text { FAsset }-\mathrm{D}-\text { Intas }}{\text { Asset }}$

شدت سودآورى: از نسبت سود خالص يس از كسر ماليات فروش بلهدست مىآيد

PIS $=\frac{\text { Net }}{\text { Sale }}$

.(Dhanora et al., 2018) شدت سرمايه: به ميزان سرمايه لازم بهازاى هر واحد محصول فروشرفته توسط شركت در فعاليتهاى توليدى اشاره دارد و از نسبت سرمايه ثابت به فروش بلهدست مي آيد (Dhanora et al., 2018). $\mathrm{KS}=\frac{\mathrm{PPE}}{\text { Sale }}$ 
ضريب نوآورى: اين متغير با استفاده از معيارهاى متفاوتى از قبيل شدت تحقيقوتوسعه، سطوح

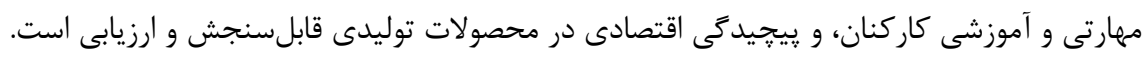

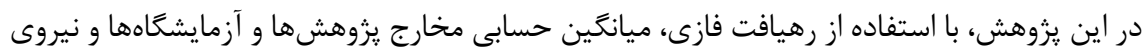

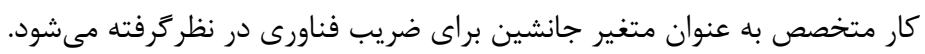
$\mathrm{RD}=\frac{1}{2}\left[\left(\frac{R \& D_{j}^{\max }-R \& D_{j}^{i}}{R \& D_{j}^{\text {max }}-R \& D_{j}^{\text {min }}}\right)+\left(\frac{L_{j}^{\max }-L_{j}^{i}}{L_{j}^{\text {max }}-L_{j}^{\text {min }}}\right)\right]$

اهرم مالى: استفاده از ابزارهاى مالى يا بدهى براى افزايش نرخ بازده سرمايهَذارى بالقوه است و

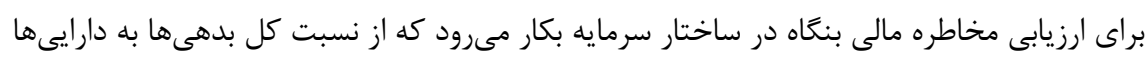
Lev $=\frac{\text { Debt }}{\text { Asset }}$ بلمدست مى آيد (فابوزى و همكاران، لهوبى (1).

بازده سهمام: به همان سود سالانه و ميزان تغييرها در قيمت سهام اشاره دارد و بهطور معمول به صورت نرخ يا درصد بيان مىشود كه در اين يزوهش از رابطه زير محاسبه مىشود (فابوزى و همكاران، هوس بان (). $\mathrm{R}=\frac{\mathrm{DPS}+\left(\mathrm{P}_{\mathrm{a}}-\mathrm{P}_{\mathrm{b}}\right)+\mathrm{BS}+\mathrm{SP}}{\mathrm{P}_{\mathrm{b}}}$

در روابط بالا، LI بيانكر درجه رقابت (شاخص لرنر)، Sale فروش، CoGs بهاى تمامشده كالاى فروشرفته، SGA هزينه عمومى، ادارى، و فروش، Net سود خالص يس از كسر ماليات، D استتهلاك، FAsset

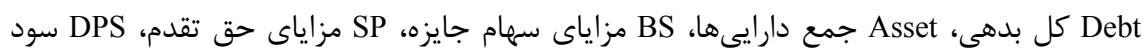

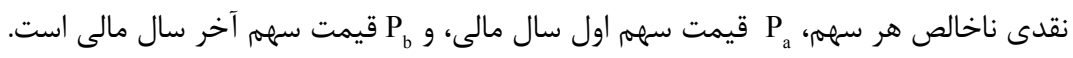

\section{يافته هاى يثروهش}

يروهش حاضر تلاش دارد دو رابطه متمايز قدرت بازارى و نوآورى، و ارتباط نوآورى و بازدهى

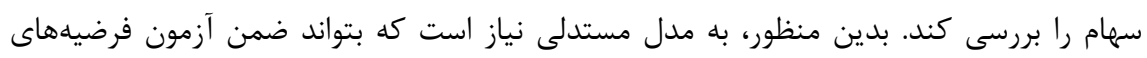

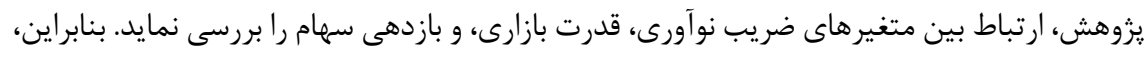

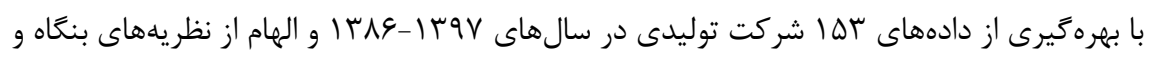

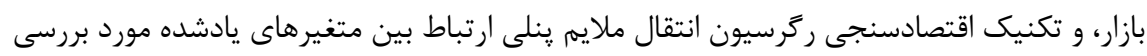

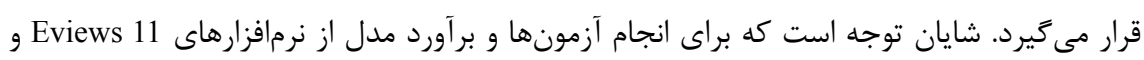


استفاده مىشود. البته يُيش از برآورد مدل لازم است به منظور جلوَيرى از ركرسيون 9.7

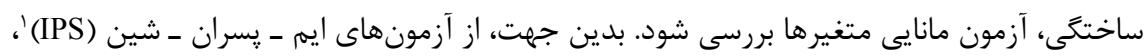

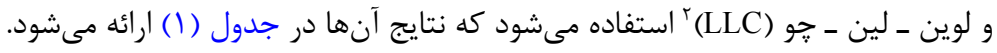

جدول ا: نتايج آزمون مانايى IPS و LLC براى متغيرها

\begin{tabular}{|c|c|c|c|c|c|}
\hline انباشتعَى درجه & معنادارى & $\begin{array}{c}\text { آماره آزمون } \\
\text { IPS }\end{array}$ & معنادارى & $\begin{array}{c}\text { آماره آزمون } \\
\text { LLC }\end{array}$ & 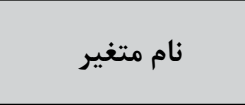 \\
\hline $\mathrm{I}(0)$ & $\cdot 1 \cdot \cdot$ & $-\Delta / 9 \Delta$ & $\cdot \cdots$ & $-10 / 99$ & قدرت بازارى LI \\
\hline $\mathrm{I}(0)$ & $\cdot 1 \cdots$ & $-1 Y / \Delta 9$ & $\cdot 1 \cdots$ & -tMF/AT & ضريب نوآورى RD \\
\hline $\mathrm{I}(0)$ & $.1 \cdots$ & $-r / 94$ & $\cdot 1 \cdot$ & $-19 / \Delta r$ & شدت مانع ورود CDR \\
\hline $\mathrm{I}(0)$ & $\cdot 1 \cdots$ & $-\mid \Delta / \mathcal{E}$ & $\cdot 1 \cdots$ & $-r \cdot / 1 t$ & R بازدهى سهام \\
\hline $\mathrm{I}(0)$ & $\cdot 1 \cdot$ & $-9 / 49$ & $\cdot 1 \cdot$ & -19191 & شدت سودآورى PIS \\
\hline $\mathrm{I}(0)$ & $\cdot 1 \cdot$ & $-9 \mid 9 Y$ & $\cdot 1 \cdots$ & 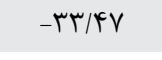 & Lev اهرم مالى \\
\hline $\mathrm{I}(0)$ & $\cdot 1 \cdots$ & $-1 \cdot / \mu r$ & $\cdot 1 \cdot$ & $-r \cdot 19 r$ & KS شدت سرمايه \\
\hline
\end{tabular}

نتايج جدول (1)، بيانكر مانا بودن متغيرها در سطح است كه اين امر بر اتكايذير بودن نتايج و

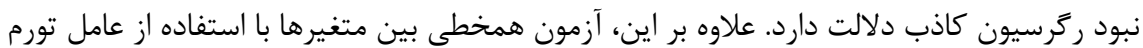
واريانس مورد بررسى قرار مى

جدول r: نتايج آزمون همخطى بين متغيرها

\begin{tabular}{|c|c|c|}
\hline VIF/1 & VIF & نام متغير \\
\hline$\cdot \mid / 499$ & $T / V T$ & قدرت بازارى \\
\hline .1948 & $1 / \cdot 1$ & ضريب نوآورى \\
\hline $.19 T \Delta$ & $1 / 9$. & شدت مانع ورود \\
\hline.$/ 91$. & $1 / \cdot r$ & بازدهى سهام \\
\hline$\cdot / T V \Delta$ & $r / \& V$ & شدت سودآورى \\
\hline.$/ 91 \mathrm{~V}$ & $1 / \cdot 9$ & اهرم مالى \\
\hline.$|9| V$ & $1 / 94$ & شدت سرمايه \\
\hline
\end{tabular}


بر اساس نتايج جدول (Y)، و بررسى همخطى بين متغير با استفاده از عامل تورم واريانس (VIF)' ملاحظه مى شود كه مشكل همخطى جدى بين متغيرهاى يزوهش وجود ندارد. در ادامه، به منظور

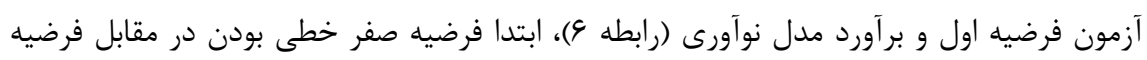

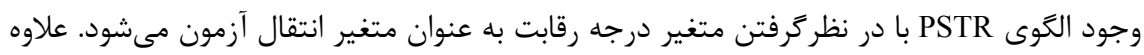
بر اين، فرض وجود رابطه غيرخطى باقيمانده به منظور تعيين تعداد توابع انتقال بررسى مى دهود كه نتايج آن در جدول (ب) مشاهده مى فئود.

جدول r: آزمون رابطه خطى در مقابل PSTR و تعداد توابع انتقال در معادله ضريب نوآورى (فناورى)

\begin{tabular}{|c|c|c|c|}
\hline & \multicolumn{3}{|c|}{ فرض وجود يك حد آستانهاى } \\
\hline & ضريب لاتر انز والد & ضريب لاكرانثر فيشر & نسبت راستنمايى \\
\hline فرضيه صفر خطى بودن در مقابل & $19 / 1 \wedge r(\cdot / \cdots)$ & $\operatorname{riqGV}(\cdot / \cdot \cdot 9)$ & $19 / r V \cdot(\cdot / \cdot r)$ \\
\hline فرض وجود يك تابع انتقال در & $\Delta / \wedge q \uparrow(\cdot / r \cdot \vee)$ & $1 / \pi 19(\cdot / \pi q 1)$ & $0 / 9 \cdot 9(\cdot / T \cdot 9)$ \\
\hline
\end{tabular}

سِّ براى انتخاب حالت بهينه ميان تابع انتقال با يك يا دو حد آستانهاى، مدل PSTR متناظر

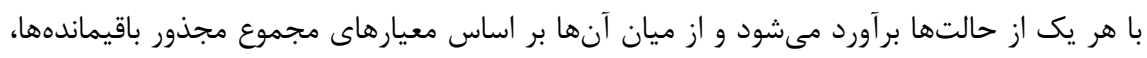

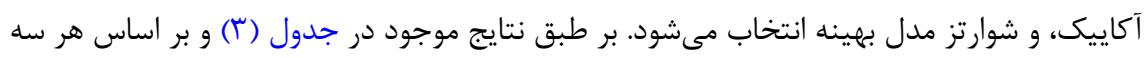

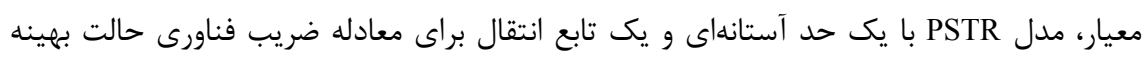

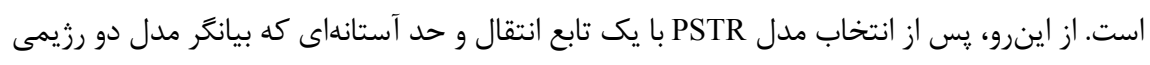

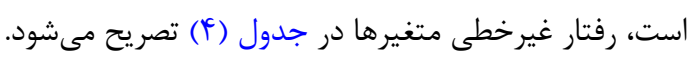


جدول ^^ نتايج بر آورد يارامترهاى مدل PSTR در معادله ضريب نوآورى (فناورى)

\begin{tabular}{|c|c|c|c|c|}
\hline \multicolumn{2}{|c|}{ بخش غير خطى مدل } & \multicolumn{2}{|c|}{ بخش خطى مدل } & \multirow{2}{*}{ متغير } \\
\hline يار امترها & ضرايب & يار پامتر ها & ضرايب & \\
\hline $\mathrm{B}_{1}$ & $-1 / \wedge 99(-\Delta / \Delta \wedge 9)$ & $a_{1}$ & $\cdot / \cdot 1 \wedge(Y / \wedge 9 \vee)$ & 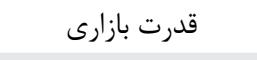 \\
\hline $\mathrm{B}_{2}$ & $\cdot / \cdot \Delta l(1 / 9 \mu \cdot)$ & $a_{2}$ & $-\cdot / \cdot r \mid(-Y / \Delta \wedge r)$ & 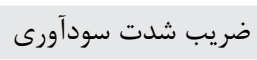 \\
\hline $\mathrm{B}_{4}$ & $-\cdot \cdot \cdot \cdot 9(-Y / V \Psi \varphi)$ & $\mathrm{a}_{4}$ & $\cdot \cdots \cdot V(T / r r \omega)$ & ضريب شدت سرمايه \\
\hline \multicolumn{5}{|c|}{$G_{j}\left(q_{i t}^{j}, \gamma, c\right)=0:$ رزيم حدى اول } \\
\hline \multicolumn{5}{|c|}{$\begin{array}{c}\mathrm{G}_{\mathrm{i}}\left(\mathrm{q}_{\mathrm{it}}^{\mathrm{j}} \gamma, \mathrm{c}\right)=1: \text { رزيم حدى دوم } \mathrm{RD}_{\mathrm{it}}=\mu_{\mathrm{i}}-1.878 \mathrm{LI}_{\mathrm{it}}+0.03 \mathrm{PIS}_{\mathrm{it}}+0.118 \mathrm{CDR}_{\mathrm{it}}-0.0053 \mathrm{KS}_{\mathrm{it}}\end{array}$} \\
\hline \multicolumn{5}{|c|}{$c=0.325, \gamma=2.0738$} \\
\hline \multicolumn{5}{|c|}{ مقادير داخل يرانتز مقدار آماره g,c c, بلهترتيب حد آستانهاى و پارامتر شيب هستند. } \\
\hline
\end{tabular}

با توجه به نتايج جدول (f))، مدل PSTR براى بررسى ارتباط بين درجه رقابت و نوآورى به صورت رابطه (ᄉ) تصريح مىشود.

$\mathrm{RD}_{\mathrm{it}}=\mu_{\mathrm{i}}+0.018 \mathrm{LI}_{\mathrm{it}}-0.021 \mathrm{PIS}_{\mathrm{it}}+0.019 \mathrm{CDR}_{\mathrm{it}}+0.0007 \mathrm{KS}_{\mathrm{it}}$

$+\left[-1.896 \mathrm{LI}_{\mathrm{it}}+0.051 \mathrm{PIS}_{\mathrm{it}}+0.099 \mathrm{CDR}_{\mathrm{it}}-0.006 \mathrm{KS}_{\mathrm{it}}\right] \mathrm{G}_{\mathrm{j}}\left(\mathrm{q}_{\mathrm{it}}^{\mathrm{j}} ; \gamma_{\mathrm{j}}, \mathrm{c}_{\mathrm{j}}\right)$

جون ضرايب تمامى متغيرها با توجه به متغير انتقال و پارامتر شيب تغيير مىيابند، نمىتوان مقدار عددى ضرايب ارائهشده در جدول (أ) را بهطور مستقيم تفسير كردو فقط بايد به تجزيهوتحليل

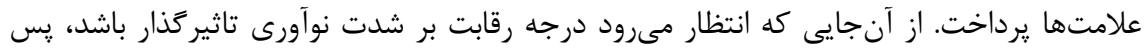
متغير درجه رقابت (شاخص لرنر)، به عنوان عامل ايجاد رابطه غيرخطى (متغير انتقال) مد نظر قرار

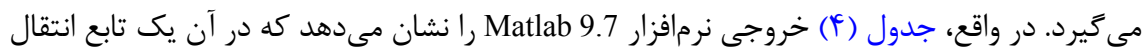

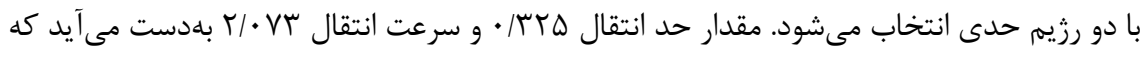
نشاندهنده جهش در انتقال از رزيمم اول به رزيم حدى دوم است. منظور از رزيم حدى اولى اول همان رزيم

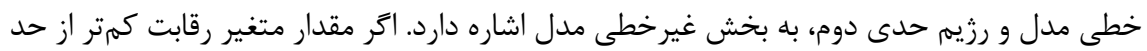

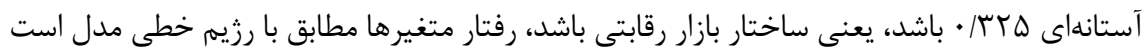
و جنانجه رقابت از حد آستانهاى هrس/ • بيشتر و ساختار بازار انحصارى شود، در رزيم غيرخطى قرار 
مى گيرد و رفتار متغيرها مطابق با رزيم حدى دوم مىشود. نتايج آزمون فرضيه اول نشان مى دهد كه با توجه به دو رزيم يادشده، متغير درجه رقابت در رزيم اول با سطح تمركز يايين، اثر مثبت و معنادارى

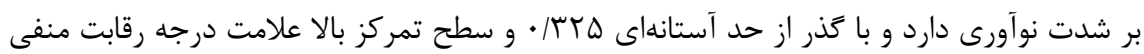

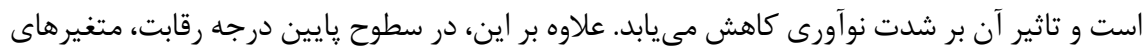

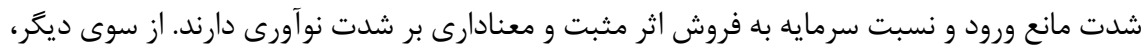
اثر متغير شدت سودآورى بر نوآورى در شركتهايى با ساختار رقابتى با مقدار ال • • • منفى و معنادار،

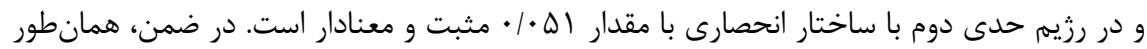

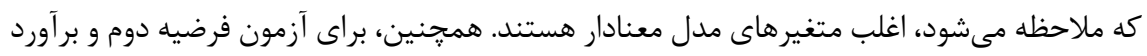

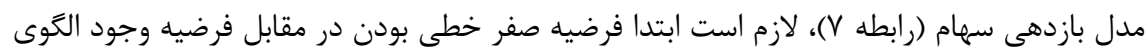

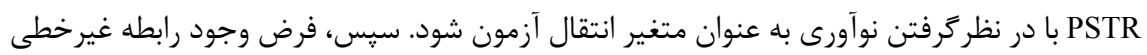

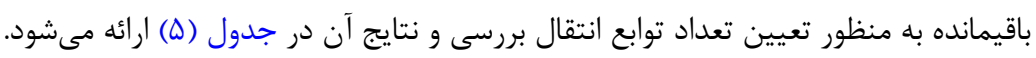

جدول ه: آزمون رابطه خطى در مقابل PSTR و تعداد توابع انتقال در معادله بازدهى سهام

\begin{tabular}{|c|c|c|c|}
\hline & \multicolumn{3}{|c|}{ فرض وجود يك حد آستانهاى } \\
\hline & ضريب لاحر انز والد & ضريب لاترانز فيشر & نسبت راستنمايیى \\
\hline فرضيه صفر خطى بودن در مقابل & $\mid F / T F \wedge(\cdot / \cdot \mid F)$ & $r / \Delta V \wedge(\cdot / \cdot r \Delta)$ & $|F / T| \Delta(\cdot|\cdot| f)$ \\
\hline فرض وجود يك تابع انتقال در & $r / I V \cdot(\cdot / T \cdot V)$ & $\cdot / \Psi \wedge \vee(\cdot \mid \Lambda \Delta \Lambda)$ & $r / I V T(\cdot / \Lambda T \Delta)$ \\
\hline
\end{tabular}

يس از انتخاب مدل PSTR با يك تابع انتقال و يك حد آستانهاى كه بيان كننده مدل دو رزيمى

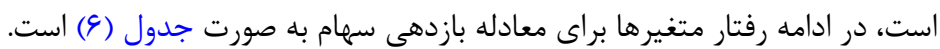


جدول צ: نتايج بر آورد بارامترهاى مدل PSTR در معادله بازدهى سهام

\begin{tabular}{|c|c|c|c|c|}
\hline \multicolumn{2}{|c|}{ بخش غير خطى مدل } & \multicolumn{2}{|c|}{ بخش خطى مدل } & \multirow{2}{*}{ متغير } \\
\hline يارامترها & ضرايب & يار امتر ها & ضرايب & \\
\hline $\mathrm{B}_{1}$ & $-1 Y K / 99(-1 / A V)$ & $\mathrm{a}_{1}$ & $r T / V \Lambda(T / r \Delta)$ & 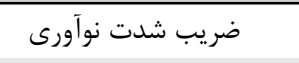 \\
\hline $\mathrm{B}_{2}$ & $-9 \Lambda / \Delta)(-\Delta / r \mu)$ & $a_{2}$ & $\| \varepsilon / F \cdot(\varepsilon / \wedge \vee)$ & ضريب قدرت بازارى \\
\hline $\mathrm{B}_{3}$ & $\cdot / \cdot 99(\Delta / \cdot \Delta)$ & $\mathrm{a}_{3}$ & $-\Phi \Delta / \mathcal{F}(-\mu / \mathcal{H} \cdot)$ & ضريب شدت مانع ورود \\
\hline $\mathrm{B}_{5}$ & $r \cdot / r T(1 / \wedge \varphi)$ & $a_{5}$ & $-.111 V(\cdot / \cdot 9 r)$ & ضريب شدت سرمايه \\
\hline \multicolumn{5}{|c|}{$\begin{array}{c}\mathrm{G}_{\mathrm{j}}\left(\mathrm{q}_{\mathrm{it}}^{\mathrm{j}} \gamma, \mathrm{c}\right)=0 \text { :رزيم حدى اول } \mathrm{R}_{\mathrm{it}}=\mu_{\mathrm{i}}+22.870 \mathrm{RD}_{\mathrm{it}}+116.021 \mathrm{LI}_{\mathrm{it}}-65.437 \mathrm{CDR}_{\mathrm{it}}+20.939 \operatorname{lev}_{\mathrm{it}}-0.117 \mathrm{KS}_{\mathrm{it}}\end{array}$} \\
\hline \multicolumn{5}{|c|}{$\begin{array}{r}G_{j}\left(q_{i t}^{j}, \gamma, c\right)=1 \text { رزيم حدى دوم: } R_{i t}=\mu_{i}-111.91 R_{i t}+17.893 L_{i t}+236.081 C D R_{i t}\end{array}$} \\
\hline \multicolumn{5}{|c|}{$c=0.153, \gamma=5.197$} \\
\hline \multicolumn{5}{|c|}{ مقادير داخل پرانتز مقدار آماره tو بهترتيب حد آستانهاى و پارامتر شيب هستند. } \\
\hline
\end{tabular}

مطابق نتايج جدول (9)، معادله بازدهى سهام در قالب رابطه (9)، و به فرم تابعى زير است.

$$
\begin{aligned}
\mathrm{R}_{\mathrm{it}}=\mu_{\mathrm{i}}+22.87 \mathrm{RD}_{\mathrm{it}}+116.02 \mathrm{LI}_{\mathrm{it}}-65.43 \mathrm{CDR}_{\mathrm{it}}+20.939 \mathrm{Lev}_{\mathrm{it}}-0.117 \mathrm{KS}_{\mathrm{it}} \\
+\left[-134.69 \mathrm{RD}_{\mathrm{it}}-98.51 \mathrm{LI}_{\mathrm{it}}+301.52 \mathrm{CDR}_{\mathrm{it}}-10.31 \mathrm{Lev}_{\mathrm{it}}\right. \\
\left.+40.317 \mathrm{KS}_{\mathrm{it}}\right] \mathrm{G}_{\mathrm{j}}\left(\mathrm{q}_{\mathrm{it}}^{\mathrm{j}} ; \gamma_{\mathrm{j}}, \mathrm{c}_{\mathrm{j}}\right)+\varepsilon_{\mathrm{it}}
\end{aligned}
$$

از آنجايى كه انتظار مىرود نوآورى بر بازدهى سهام تاثيرگذار باشد، بنابراين در معادله بازدهى

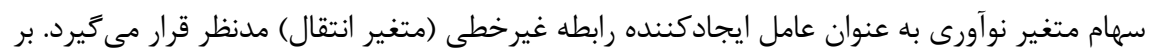

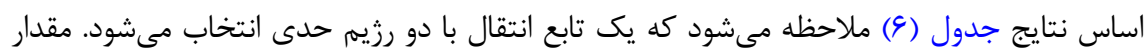

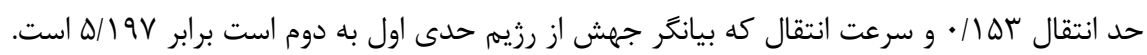

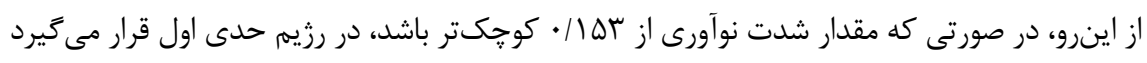

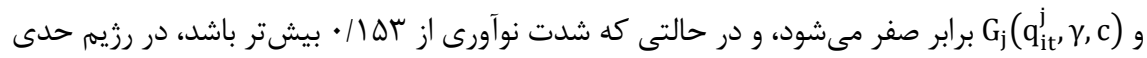

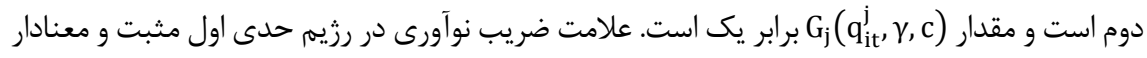

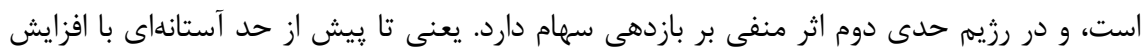

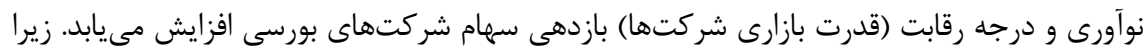

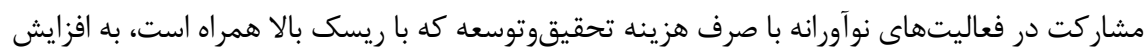


قدرت بازارى شركتها منجر مىشود و ساختار بازار را از رقابت به انحصار جندجانبه هدايت مى كند. از

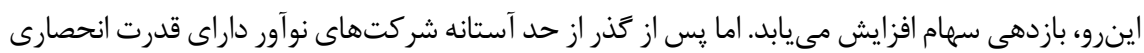
به دليل قرار گرفتن در حاشيه امن، ريسكيذيرى كمترى دارند و بازدهى سهام كاهش مي يابد. علاوه بر اين، در شركتهايى كه مخارج اندكى صرف نوآورى مىشود، شدت سرمايه اندك و مانع ورود جندان مرتفع نيست، بنابراين بازار را به سمت ساختار رقابتى سوق مىدهند كه اين امر ريسك و بازدهى سهام

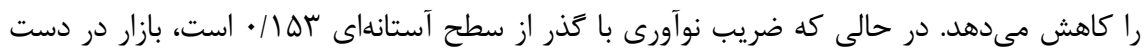
تعداد محدودى شركت قرار مى گيرد. با گسترش شدت سرمايه و مانع ورود ساختار، بازار به سطح ميانى

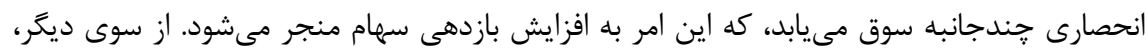

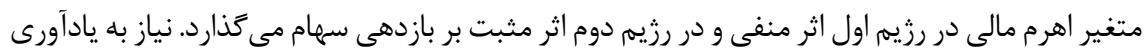
است كه در اين معادله نيز اغلب متغيرهاى مدل معنادار هستند. در حقيقت، هر دو الكو تاثير نامتقارن

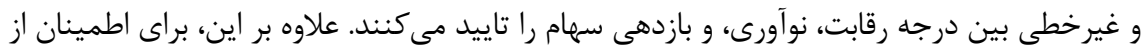
اين امر نياز است كه نمودار رابطه درجه رقابت و شدت نوآورى، و ارتباط شدت نوآورى و بازدهى سهرئ سهام

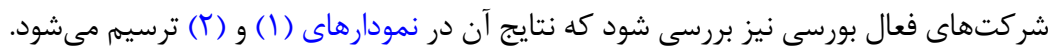

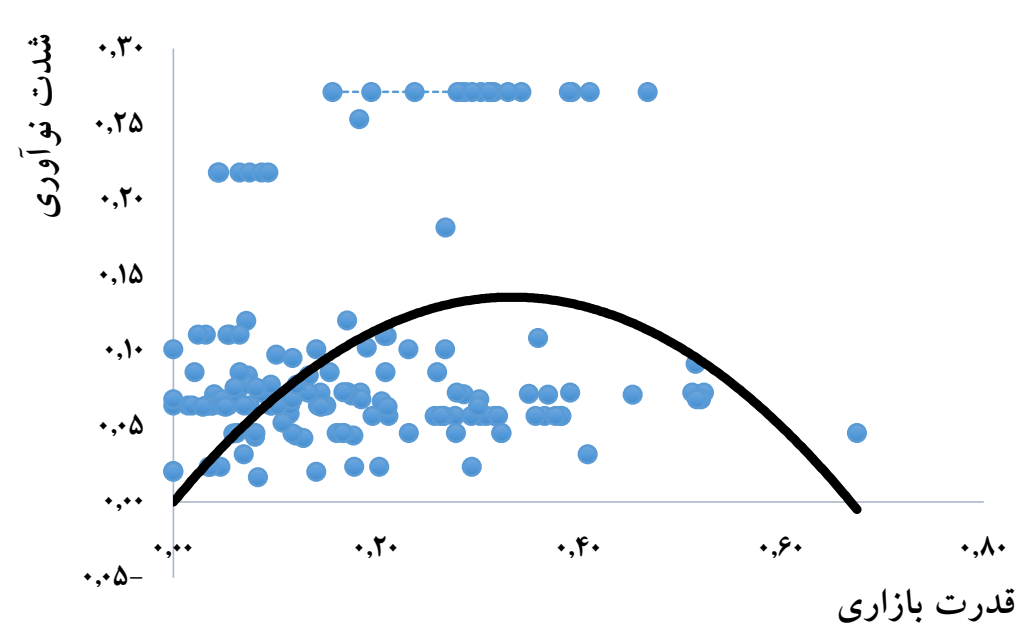




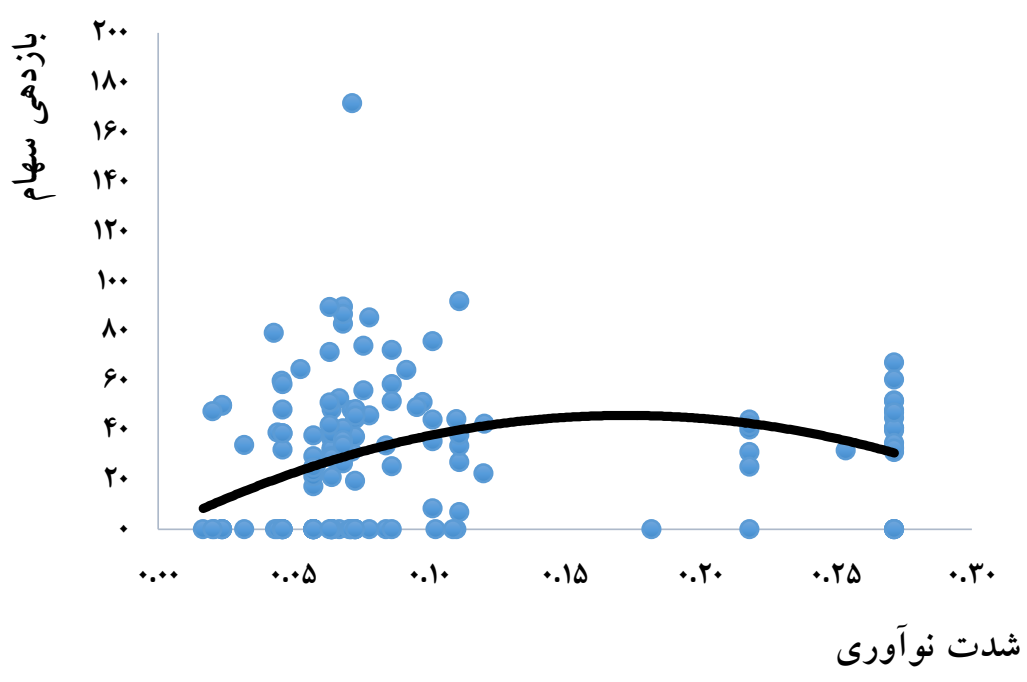

نمودار (ץ): رابطه نوآورى و بازدهى سهام

با توجه به نمودار ( (1)، مشخص مىشود كه در سطوح پايين و بالاى درجه رقابت اندازه نوآورى

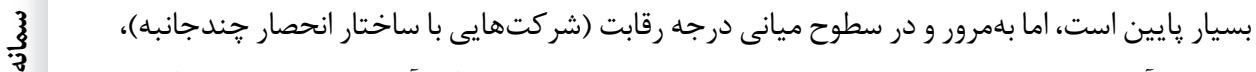

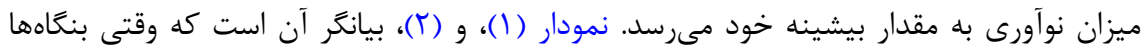

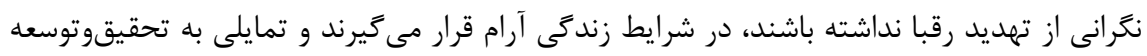
ندارند. علاوه بر اين در نمودار (Y) ملاحظه مىشود كه در سطوح يايين نوآورى ميزان بازدهى سهر سهام

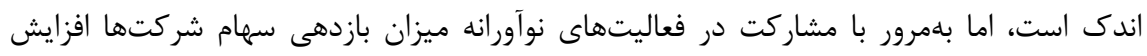

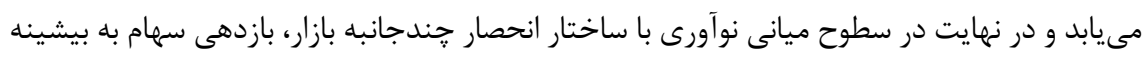

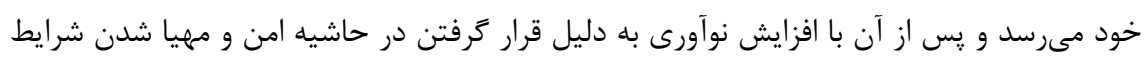

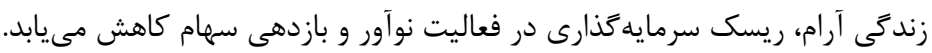


هدف اصلى يزوهش حاضر، شناخت دو رابطه متمايز بين قدرت بازارى و نوآورى، و تاثير شدت

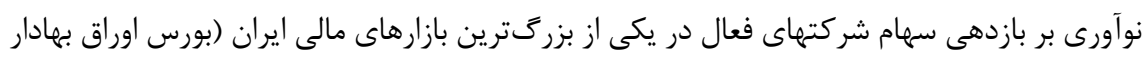

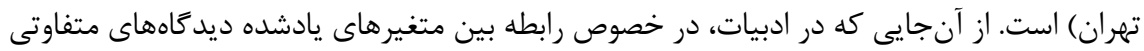
مطرح مىشود و بين دانشمندان توافق نظرى وجود ندارد، نياز است اين موضوع به صورت تجربى

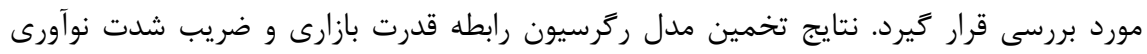

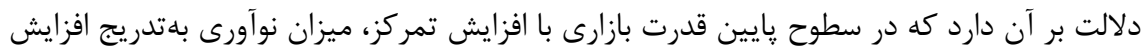

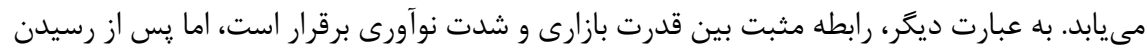

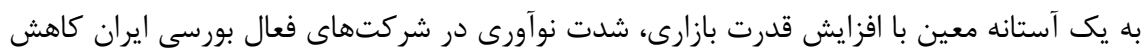

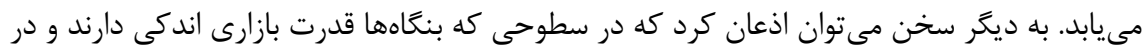

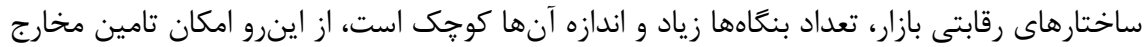

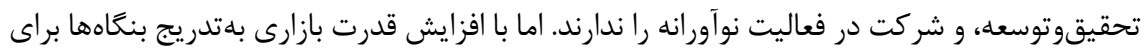

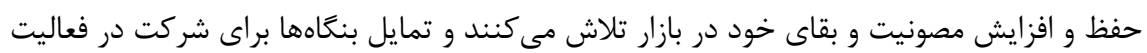

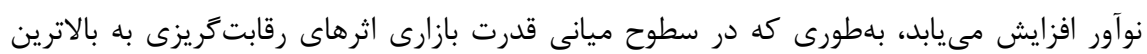

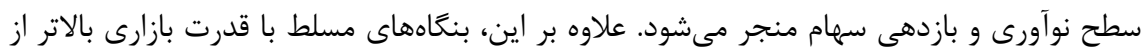

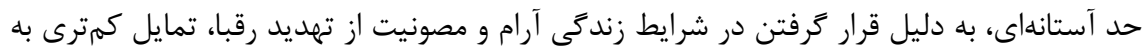

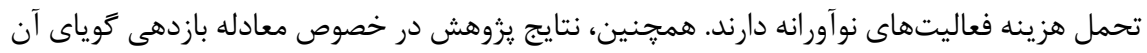

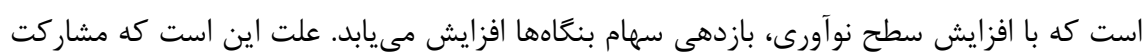

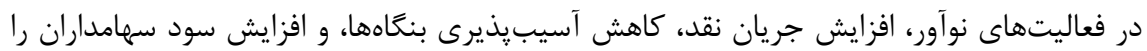

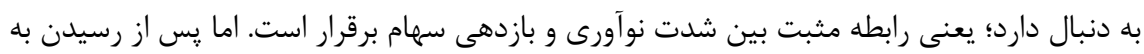

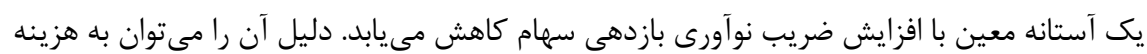

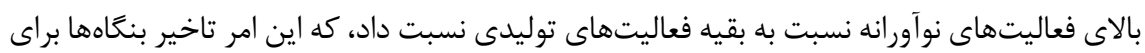
دستيابى به نوآورى برتر و جريان نقد كمتر را به همراه دارد. به عبارت ديكر، در سطوح بالا و وايين

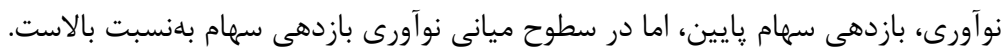
يافتههاى يزوهش با واقعيت ايران ساز تامين مخارج تحقيقوتوسعه فراهم نيست. حتى اگر اين بنگًاههاى كوجٍى به هر ترتيبى قادر به تامين 
مالى مخارج تحقيقوتوسعه و فعاليت نوآور باشند، اما ريسك ناشى از تقليد ساير رقبا را نمىتوانند

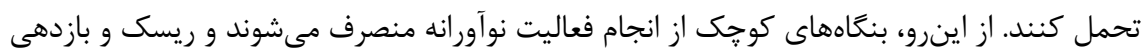
سهام كمترى را تجربه مى كنند. اما در خصوص بنگاههايى با قدرت بازارى متوسط، به دليل اينكه

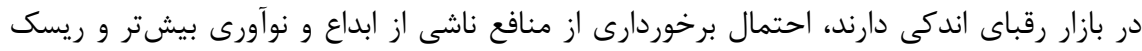
تقليد ساير رقبا كمتر مىشود. در اين شرايط، شركتهاى نوآور در صورت موفقيت مىتوانند بر بازار

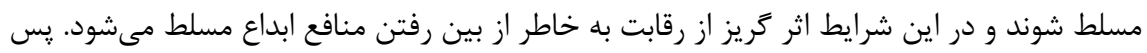

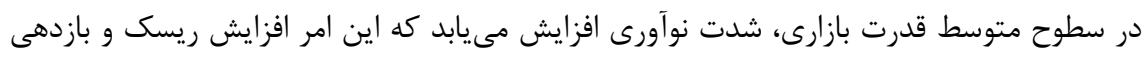

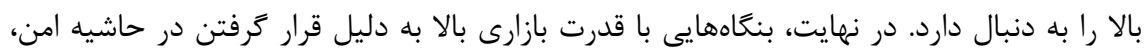

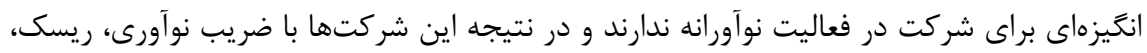

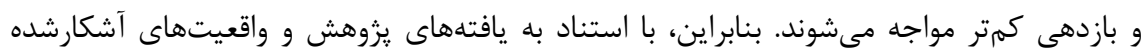
مى توان ملاحظه كرد كه در شركتهاى فعال بورسى ايران، علاوه بر رفتار و تاثير نامتقارن متغيرها، وجود رابطه U معكوس تاييد مىشود.

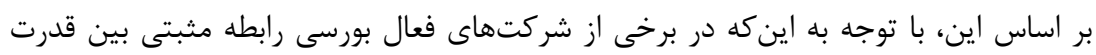

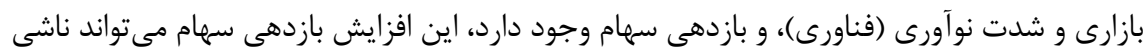

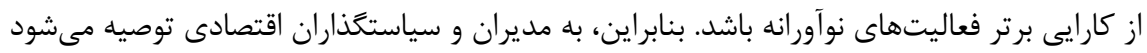

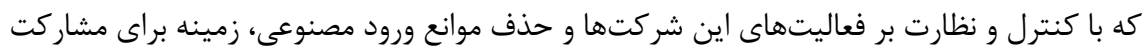
بيشتر در فعاليتهاى نوآورانه فراهم شود. به دليل اينكه در بيشتر بنكاههاى فعال بورسى رابطه

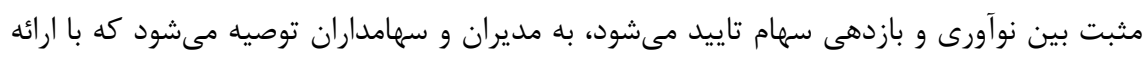

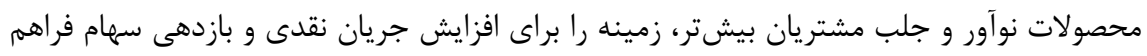

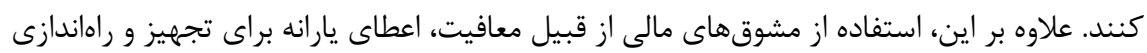
واحدهاى تحقيقوتوسعه به دولت توصيه مىشود. به سياستخذاران توسعه صنعتى افزايش بودجه يزوهشهاى صنعتى و اعطاى تسهيلات با نرخ سود يايين به واحدهاى نوآور ييشنهاد مىشود.

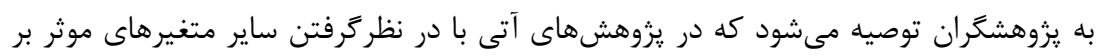
نوآورى و بازدهى سهام بر غناى يزوهش حاضر بيافزايند. 


\section{الف) فارسى}

منابع

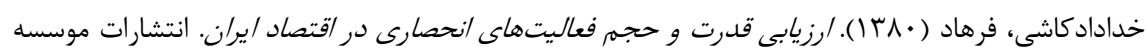

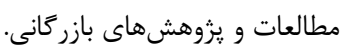

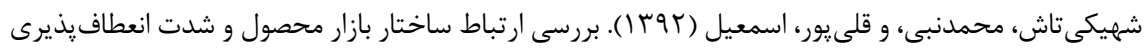

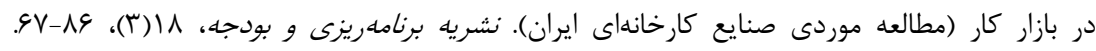
.http://jpbud.ir/article-1-1071-fa.html

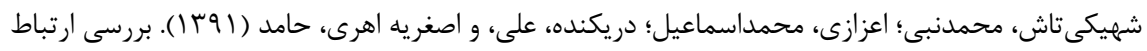

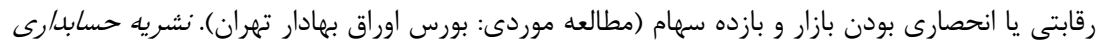

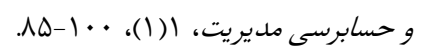

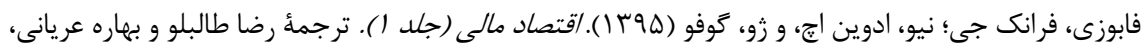

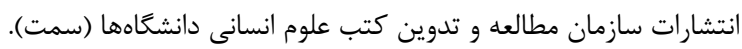

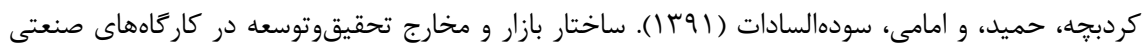

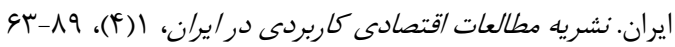

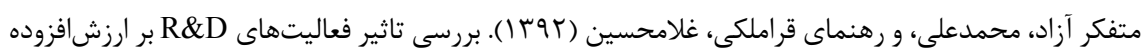

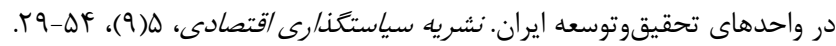

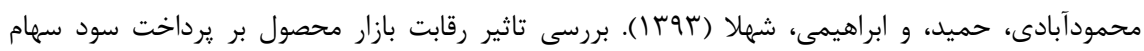

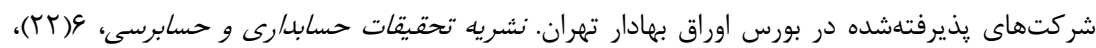
.http://www.iaaaar.com/article_104391.html .9ł-1.9

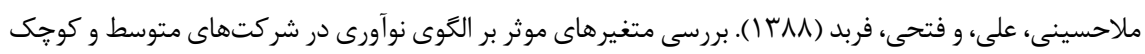

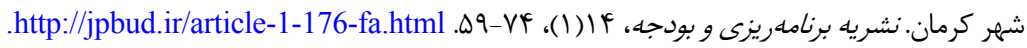

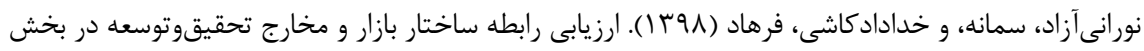

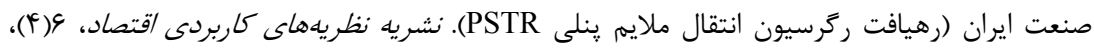
.rV-QT

Aghion, P., Bloom, N., Blundell, R., Griffith, R., \& Howitt, P. (2005). Competition and Innovation: An Inverted-U Relationship. The Quarterly Journal of Economics, 120(2), 701-728. https://doi.org/10.1093/qje/120.2.701.

Alfranca, O., Voces, R., Herruzo, A. C., \& Diaz-Balteiro, L. (2014). Effects of Innovation 
on the European Wood Industry Market Structure. Forest Policy and Economics, 40(1), 40-47. https://doi.org/10.1016/j.forpol.2013.12.001.

Arrow, K. J. (1972). Economic Welfare and the Allocation of Resources for Invention. Readings in Industrial Economics (pp. 219-236): Springer.

Bonfatti, R., \& Pisano, L. (2020). Credit Constraints and the Inverted-U Relationship between Competition and Innovation. Economica, 87(346), 442-469. https://doi.org/10.1111/ecca.12312.

Chernyshev, N. (2017). The Relationship between R\&D and Competition: Reconciling Theory and Evidence. CDMA Working Paper Series, No. 1704. http://hdl.handle.net/10023/11789.

Clarke, R., \& Davies, S. W. (1982). Market Structure and Price-Cost Margins. Economica, 49(195), 277-287.

Clarke, R., Davies, S., \& Waterson, M. (1984). The Profitability-Concentration Relation: Market Power or Efficiency? The Journal of Industrial Economics, 32(4), 435-450.

Colletaz, G., \& Hurlin, C. (2006). Threshold Effects of the Public Capital Productivity: An International Panel Smooth Transition Approach. Working Paper, 1/2006, LEO, Université d'Orléans, 1-39.

Dhanora, M., Sharma, R., \& Khachoo, Q. (2018). Non-Linear Impact of Product and Process Innovations on Market Power: A Theoretical and Empirical Investigation. Economic Modelling, 70(1), 67-77. https://doi.org/10.1016/j.econmod.2017.10.010.

Fok, D., Van Dijk, D., \& Franses, P. H. (2005). A Multi-Level Panel STAR Model for US Manufacturing Sectors. Journal of Applied Econometrics, 20(6), 811-827. https://doi.org/10.1002/jae.822.

Galbraith, J. K. (1952). American Capitalism, The Concept of Countervailing Power: Houghton Mifflin Company.

Gonzalez, A., Terasvirta, T., and Van Dijk, D. (2005). Panel Smooth Transition Regression Models, SEE/EFI Working Paper Series in Economics and Finance, No. 604.

Goodwin, M. (1998). Firm Size and R\&D; Testing the Schumpeterian Hypothesis. University Avenue Undergraduate Journal of Economics, 2(1), 1-8.

Grullon, G., \& Michaely, R. (2007). Corporate Payout Policy and Product Market Competition. Paper Presented at the AFA 2008 New Orleans Meetings Paper.

Gunday, G., Ulusoy, G., Kilic, K., \& Alpkan, L. (2011). Effects of Innovation Types on Firm Performance. International Journal of Production Economics, 133(2), 662-676. https://doi.org/10.1016/j.ijpe.2011.05.014.

Hart, O. D. (1983). The Market Mechanism as an Incentive Scheme. The Bell Journal of Economics, 14(2), 366-382.

Hashmi, A. R., \& Biesebroeck, J. V. (2016). The Relationship between Market Structure and Innovation in Industry Equilibrium: A Case Study of the Global Automobile Industry. Review of Economics and Statistics, 98(1), 192-208. https://doi.org/10.1162/REST_a_00494.

He, W. (2012). Agency Problems, Product Market Competition and Dividend Policies in Japan. Accounting \& Finance, 52(3), 873-901. https://doi.org/10.1111/j.1467629-X.2011.00414.x.

Hirshleifer, D., Hsu, P.-H., \& Li, D. (2013). Innovative Efficiency and Stock Returns. Journal of Financial Economics, 107(3), 632-654. https://doi.org/10.1016/j.jfineco.2012.09.011.

Hou, K., \& Robinson, D. T. (2006). Industry Concentration and Average Stock Returns. The 
Journal of Finance, 61(4), 1927-1956. https://doi.org/10.1111/j.15406261.2006.00893-.x. Marshall, G., \& Parra, A. (2019). Innovation and Competition: The Role of the Product Market. International Journal of Industrial Organization, 65(1), 221-247. https://doi.org/10.1016/j.ijindorg.2019.04.001.

Peneder, M., \& Wörter, M. (2014). Competition, R\&D and Innovation: Testing the Inverted-U in a Simultaneous System. Journal of Evolutionary Economics, 24(3), 653687. https://doi.org/10.1007/s00191-013-0310-z.

Rickard, S. (2006). The Economics of Organizations and Strategy: McGraw-Hill Education. Schumpeter, J. (1942). Capitalism, Socialism and Democracy: Harper.

Schumpeter, J. A. (1934). The Theory of Economic Development ... by Joseph A. Schumpeter, Translated from the German by Redvers Opie: Harvard University Press.

Sharma, V. (2011). Stock Returns and Product Market Competition: Beyond Industry Concentration. Review of Quantitative Finance and Accounting, 37(3), 283-299. 10.1007/s11156-010-0205-0.

Szutowski, D. (2019). Innovation Source, Advancement Stage and Company Stock Returns. The Service Industries Journal, 39(13-14), 925-942. https://doi.org/10.1080/02642069.2018.1450869.

Thanh, S. D. (2015). Threshold Effects of Inflation on Growth in the ASEAN-5 Countries: A Panel Smooth Transition Regression Approach. Journal of Economics, Finance and Administrative Science, 20(38), 41-48. https://doi.org/10.1016/j.jefas.2015.01.003.

Udriyah, U., Tham, J \& Azam, S. (2019). The Effects of Market Orientation and Innovation on Competitive Advantage and Business Performance of Textile SMEs. Management Science Letters, 9(9), 1419-1428. http://www.growingscience.com/msl/Vol9/msl_2019_122.pdf. 